\title{
Violence among foragers: The bioarchaeological record from central California
}

\author{
Al W. Schwitalla ${ }^{\mathrm{a}}$, Terry L. Jones ${ }^{\mathrm{b}, *}$, Marin A. Pilloud ${ }^{\mathrm{c}}$, Brian F. Codding ${ }^{\mathrm{d}}$, Randy S. Wiberg ${ }^{\mathrm{e}}$ \\ ${ }^{a}$ Millennia Archaeological Consulting, 3708 Bigler Way, Sacramento, CA 95817, United States \\ ${ }^{\mathrm{b}}$ Department of Social Sciences, California Polytechnic State University, San Luis Obispo, CA 93407-0329, United States \\ ' Central Identification Laboratory, Joint POW/MIA Accounting Command, JBPHH, HI, United States \\ ${ }^{\mathrm{d}}$ Department of Anthropology, University of Utah, 270 S. 1400 E., Rm. 102, Salt Lake City, UT 84112, United States \\ ${ }^{\mathrm{e}}$ Holman and Associates Archaeological Consulting, 1201 Pine Street, Unit 142, Oakland, CA 94607, United States
}

\begin{abstract}
A B S T R A C T
Spatial and diachronic patterns in skeletal evidence for three forms of violence were evaluated for central California with information from a bioarchaeological database that contains information on 16,820 burials from 329 sites. The most abundant form of violence was sharp force/projectile trauma (462/6278, $7.4 \%)$, followed by blunt force craniofacial trauma (264/6202, 4.3\%) and trophy-taking/dismemberment $(87 / 12,603,0.7 \%)$. Signs of violence were concentrated in the area with the highest ethnographic population densities (Sacramento River), but also in the southern San Francisco Bay area which seems to have been a contested interface zone between established residents and incoming migrants. Sharp force/projectile trauma was also high in the Sierra Nevada following introduction of the bow and arrow, and violence in general was more common among males, although there is less of a sex-difference among individuals with blunt force craniofacial injuries in central California relative to southern California, suggesting greater participation by females in this form of violence as attested by historic eyewitness accounts. Temporal patterning shows two episodes of elevated violence: the Early Middle Period (500 cal B.C.-cal A.D. 420) when trophytaking/dismemberment peaked, and the Protohistoric/Historic Period (cal A.D. 1720-1899) marked by high levels of blunt force craniofacial and projectile trauma. The Protohistoric/Historic peak, preceded by the appearance of the bow and arrow ca. A.D.1000-1200 and an associated upturn in projectile violence, is attributed to the arrival of Europeans into southwestern North America 250 years before their permanent settlement in California ca. A.D. 1769.
\end{abstract}

\section{Introduction}

Overlooked and under-reported for much of the latter half of 20th century, violence among foragers has been a growing focus of archaeological research in California and beyond in the last two decades (Allen, 2012; Andrushko et al., 2005; Bartelink et al., 2013; Chacon and Dye, 2007; Fry, 2006; Guilane and Zammit, 2001; Johnson, 2007; Jurmain, 2001; Jurmain et al., 2009; Jurmain and Bellifemine, 1997; Keeley, 1996; Kelly, 2000; Kennett, 2005; Kennett and Kennett, 2000; Lambert, 2007a, 1994, 1997, 2002, 2007b, 2012; LeBlanc, 1999; Martin and Frayer, 1997; Maschner, 1997; Maschner and Reedy-Maschner, 1998; Smith, 1997; Walker, 1989; Walker and Lambert, 1989). As put most aptly by Keeley (1996) a certain de-emphasis on inter-group conflict and warfare was a hallmark of many anthropological studies from the 1960s

\footnotetext{
* Corresponding author.

E-mail addresses: alschwitalla@millenniareproductions.com (A.W. Schwitalla), Tljones@calpoly.edu (T.L. Jones), marin.pilloud@jpac.pacom.mil (M.A. Pilloud), brian.codding@anthro.utah.edu (B.F. Codding), rwiberg@comcast.net (R.S. Wiberg).
}

through 1980s as researchers sought consciously or unconsciously to minimize the occurrence of ecological and/or social problems in pre-industrial societies. In California, the ethnohistoric record documents violence and inter-group conflicts among native foraging populations (Allen, 2012; Johnson, 2007; McCorkle, 1978; Sutton, 1986), but widely-read books such as The Ohlone Way (Margolin, 1978 ) tended to overlook evidence for social and environmental ills, promoting instead images of ecological balance and political harmony as outgrowths of culturally mediated egalitarianism and resource stewardship. While bioarchaeological evidence for inter-personal violence was noted by some early on (e.g., Heizer, 1949; James and Graziani, 1975; Pastron et al., 1973) this was not a major focus of research in the 1960s-1980s or in similarlyminded studies that have followed (e.g., Goerke, 2007; Lightfoot and Parrish, 2009).

Following a ground-breaking study of the bioarchaeology of violence in small-scale societies by Milner et al. (1991), the trend to overlook violence in California was countered most decisively in the 1990s by the research of Lambert and Walker (Lambert, 
1994, 1997; Walker, 1989; Walker and Lambert, 1989) who examined skeletal remains and burial records from the ethnographic Chumash area of southern California collected between the 1920s and 1960s. Lambert (1994) tabulated a series of traits indicative of violence (forearm parry fractures, cranial injuries, and projectile injuries) from 1774 skeletons dating from ca. 5500 cal B.C. (Lambert, 2012) to post-contact, and ordered her findings chronologically using field notes, earlier publications, and radiocarbon dates. With this large sample and a rigorous, multi-faceted analysis, Lambert documented a peak in violence during the Late Middle Period (ca. cal A.D. 580-1380) on the southern coast, and established unequivocally that California was not violence-free prior to the arrival of Europeans. She also related the trend in violence to climatic/environmental conditions, arguing that resource scarcity during droughts of the Medieval Climatic Anomaly was a major cause of inter-personal hostility. This was an extension of ideas proposed earlier by Walker (1989) who emphasized extreme demographic pressure on the islands off southern California as a potentially major cause of violence. He argued that the unusually high frequency of nonlethal cranial injuries on the islands reflected sublethal ritualized fighting that was ultimately the result of "intense competition over resources in a geographically circumscribed [island] environment" (Walker, 1989:313). These hypotheses ultimately precipitated a decades-long debate over the relationship between climate and emergent socio-political complexity in Native California (e.g., Arnold, 1997; Basgall, 1999; Bettinger, 1999; D’Oro, 2009; Gamble, 2005; Jazwa et al., 2012; Johnson, 2004; Jones et al., 1999; Jones and Schwitalla, 2008) that included some continued emphasis on violence (e.g., Fischman, 1996; Kennett, 2005; Kennett and Kennett, 2000; Raab and Larson, 1997). In sum, the seminal violence studies from southern California emphasized population density, extreme climatic variation, and also the introduction of new weaponry (the bow and arrow) as key variables influencing rates of violence among these hunter-gatherer populations. Lambert's (1994) data suggested that the bow appeared in the Channel area ca. A.D. 900 and was also a contributing factor in a marked upturn in projectile violence during the Late Middle Period. This perspective is generally consistent with longstanding ecological views on violence that relate it directly to environment, resource scarcity, and/or population (see Ember and Ember, 1992; Otterbein, 1999; Vayda, 1976) in both human and non-human groups (Peterson and Wrangham, 1996). More specifically, the correlation between an apex in violence and drought-related resource stress in the Santa Barbara area supports an influential cross-cultural analysis by Ember and Ember (1992) that found a correlation between societies with acute food shortages and warfare. Commonly, this ecological view also attributes the inclination toward violence more to males than females (Peterson and Wrangham, 1996) which Lambert's (1994) findings from the Santa Barbara Channel supported. Lambert (1994) also equated a relatively low frequency of violence among earlier (pre $1500 \mathrm{cal}$ B.C.) burials in her sample with egalitarian, band-like political structure and increased frequencies later in time with more complex political organization.

In central California, earlier small-scale studies demonstrating presence of violence (James and Graziani, 1975; Pastron et al., 1973) have been eclipsed by analyses of large populations from single sites; Jurmain (2001) documented a $4.4 \%$ cranial injury frequency and $3.7 \%$ projectile point injury in 162 burials from the Middle and Late Period Yukisma Creek site (CA-SCL-38) in the San Francisco Bay area, while more recently Jurmain et al. (2009) reported $4.4 \%$ projectile point injury and other evidence of interpersonal aggression in 503 burials from the Ryan Mound (CAALA-329). Andrushko et al. (2010) was the first multi-site study to consider evidence for regional violence. Using a preliminary version of the same database we rely on here ( $n=13,453$ burials), these authors reported 76 individuals with perimortem removal of body parts consistent with trophy-taking or dismemberment. Like Lambert (1994) they equated patterning in this one aspect of violence with emergent socio-political complexity although the presence of this particular form of violence contrasts markedly with the Santa Barbara Channel where Lambert (1994) and Walker (1989) reported no evidence for trophy-taking or dismemberment. Temporal patterning was also quite different; Andrushko et al. (2010) found that trophy-taking reached its highest frequency during the Early/Middle Transition period (500-200 cal B.C.) in central California, whereas, violence in the Santa Barbara Channel showed a bi-modal distribution with cranial vault fractures peaking during the Early Middle Period (1400 cal B.C.-cal A.D. 580) and projectile wounds reaching their apex between cal A.D. 580 and 1380. As Pastron (1973) had discovered earlier, Andrushko et al. (2010) and Bartelink et al. (2013) also found that evidence for violence seemed to be concentrated in certain locations, particularly the southern San Francisco Bay area. Andrushko et al. (2010) further suggested that in-migration of new peoples brought with it heightened levels of inter-personal hostility, and that the occurrence of female victims of trophy-taking demonstrated "reciprocal violence in which there was social substitution of noncombatant individuals" (Andrushko et al., 2010:90). Thus most of the variables considered critical to understanding the relative frequency of and cultural variation in violence among foragers have been touched on in reference to the ethnohistory and bioarchaeology of Native California: environment, population, level of socio-political organization, sex, cultural variation, and/or stochastic events.

Here we consider these variables in an evaluation of basic spatial and temporal patterns manifest in a large bioarchaeological database for central California that includes information on 16,820 individual burials from 329 archaeological sites (Fig. 1) excavated between late 19th century and the present although the majority ( $\sim 80 \%$ ) was uncovered after 1975 . Lambert (2007a) summarized all of the then-available evidence for pre-contact violence for California as a whole, but her data were heavily weighted toward the Santa Barbara Channel owing to the dispersed nature of osteological information from other parts of the state. Our goal here is to complement Lambert's seminal work and the preliminary findings from central California (Andrushko et al., 2005, 2010; Bartelink et al., 2013; Jurmain, 2001; Jurmain et al., 2009; Jurmain and Bellifemine, 1997; Nelson, 1997) with additional skeletal evidence for violence. Specifically, we supplement the existing trophy-taking and dismemberment data with new findings, and add to this, evidence for other indications of violence: blunt force craniofacial trauma, sharp force trauma, and projectile injuries. The ethnohistoric territories from which the remains were recovered show variation in population density, political organization, environment, and subsistence adaptation which have allowed us to evaluate possible correlations between frequencies/types of violence and variables that are considered critical according to alternative theoretical views and hypotheses. Specifically, we evaluated spatial and temporal patterns in signs of violence, made comparisons with the Santa Barbara Channel, and further considered possible correlations between levels of violence and (1) population density, (2) socio-political complexity, and (3) relative involvement of males versus females and young versus old members of populations. We have also evaluated temporal patterns relative to climatic variation and historic/cultural events, specifically the introduction of new weaponry in the form of the bow and arrow. Ultimately, our study tests the hypothesis that environmental and other external factors influenced specific patterns and prevalence of violence among hunter-gatherer populations in California. This hypothesis predicts that outbreaks of violence, and violence in general, are linked to circumstances of 


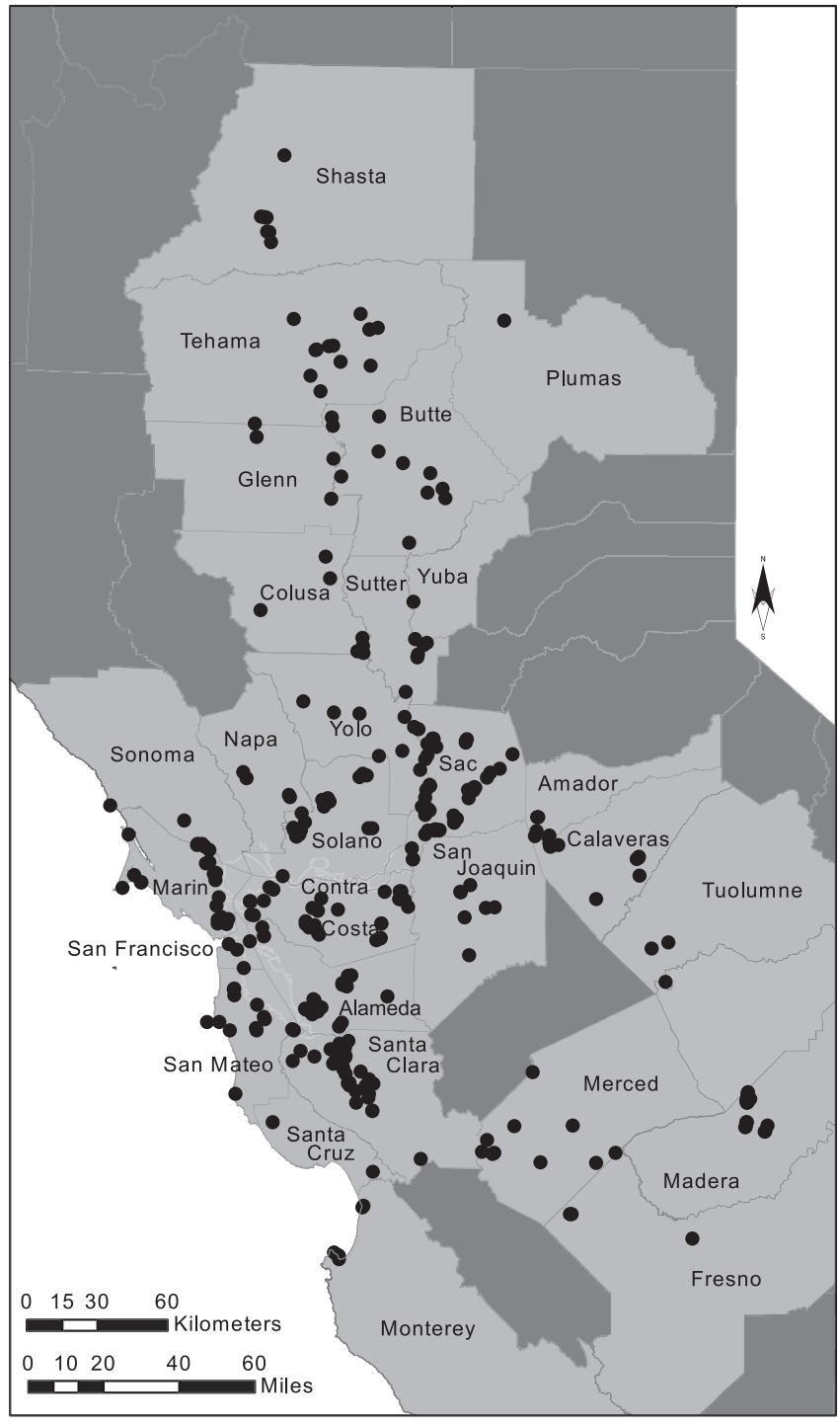

Fig. 1. Archaeological sites in the central California bioarchaeological data base.

acute resource stress and competition along the lines proposed by Ember and Ember (1992).

\section{Contextual background}

\section{Ethnographic territories and ethnohistory}

Our database provides comparative information from three major geographic regions of California: the San Francisco Bay area, Central Valley (Sacramento and San Joaquin River drainages), and Sierra Nevada foothills. At the time of contact, these regions were inhabited by populous, broad-spectrum huntergatherers who were considerably less maritime than residents of the Santa Barbara Channel. Northern California people were organized into a multitude of relatively small autonomous tribelets that are usually aggregated for research and reporting purposes into larger groupings based on environment, population concentrations, and shared languages. Our study area encompasses 19 of these ethnohistoric territorial delineations (Fig. 2, see Table 1). Linguistic evidence gathered over the past one hundred years has demonstrated that these territories were likely not stable over time (see Golla, 2011; Kroeber, 1925; Moratto,

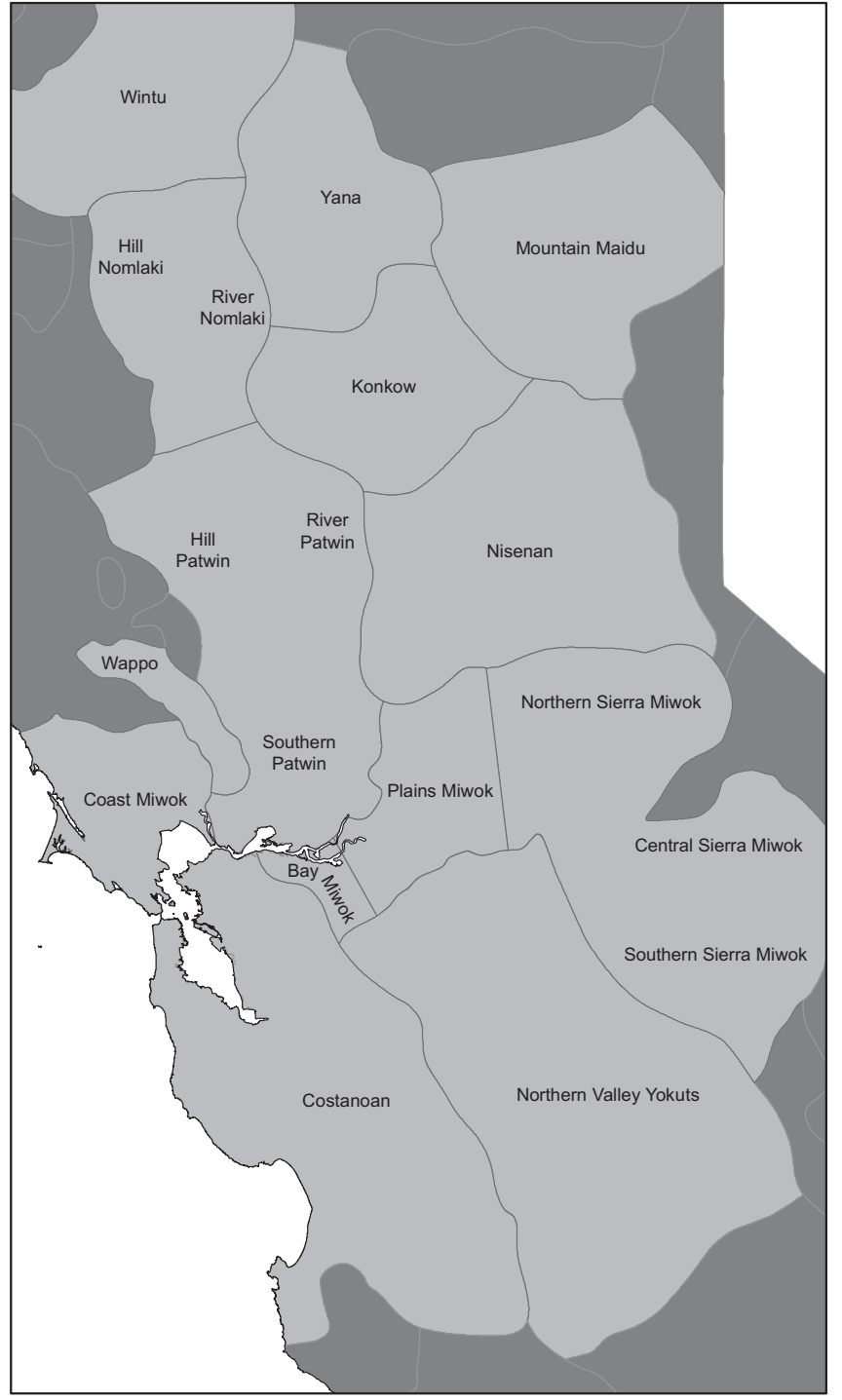

Fig. 2. Ethnographic tribal territories represented in the central California bioarchaeological database.

1984; Shipley, 1978), and there is little if any reason to think that they are strictly applicable to all geographic regions and temporal phases represented in the archaeological record. However, they do encompass relatively discrete, stable clusters of environmental characteristics and are useful for making spatial comparisons.

All of these groups were marked by relatively broad-spectrum foraging with greater or lesser degrees of reliance on the acorn as a stored staple. Artifact assemblages (Basgall, 1987), macrobotanical studies (Wohlgemuth, 2004), and isotopic analysis of human bone (Bartelink, 2009) generally show an increasing focus on the acorn over time. Salmon and other fisheries were also important to those groups residing along the banks of the Sacramento and San Joaquin rivers and their tributaries. Early ethnographies are frustratingly unclear on the exact manner in which subsistence was accomplished vis-à-vis mobility, but groups residing along the major rivers and who relied intensively on mixes of salmon and acorns seem to have been largely sedentary (Table 1) while others, such as the Costanoan, Coast and Bay Miwok, were more omnivorous and semi-sedentary. Groups in the foothills of the Sierra Nevada and Coast Ranges were clearly more mobile, engaging in yearly cycles of transhumance. 
Table 1

Ethnographic territories represented in the central California bioarchaeological database.

\begin{tabular}{|c|c|c|c|c|c|c|c|c|c|}
\hline Territory & $\begin{array}{l}\text { Geographic } \\
\text { region }\end{array}$ & Habitat & $\begin{array}{l}\text { Population } \\
\text { density } \\
\text { people/mile } 2\end{array}$ & $\begin{array}{l}\text { Data } \\
\text { source }\end{array}$ & $\mathrm{N}$ sites & $\begin{array}{l}\mathrm{N} \text { sites with } \\
\text { evidence of } \\
\text { violence }\end{array}$ & $\mathrm{N}$ burials & $\begin{array}{l}\text { Ethnographic } \\
\text { political } \\
\text { structure }\end{array}$ & $\begin{array}{l}\text { Ethnographic } \\
\text { mobility } \\
\text { adaptation }\end{array}$ \\
\hline Bay Miwok & S.F. Bay & Estuary & 4.3 & Cook (1976) & 24 & 10 & 1681 & Tribelet & Semi-sedentary \\
\hline Coast Miwok & S.F. Bay & Open Coast & 4.3 & Cook (1976) & 25 & 9 & 379 & Tribelet & Semi-sedentary \\
\hline Costanoan & S.F. Bay & Estuary/Open Coast & 2.4 & Cook (1976) & 98 & 54 & 6475 & Complex Tribelet & Semi-sedentary \\
\hline Wappo & S.F. Bay & $\begin{array}{l}\text { Foothills/Oak } \\
\text { Woodland }\end{array}$ & 4.3 & Cook (1976) & 2 & 0 & 26 & Tribelet & Semi-sedentary \\
\hline Hill Nomlaki & Sacramento Valley & Foothills & 2.0 & Cook (1976) & 2 & 2 & 553 & Complex Tribelet & Seasonally mobile \\
\hline Hill Patwin & Sacramento Valley & $\begin{array}{l}\text { Foothills/Prairie-Oak } \\
\text { Woodland }\end{array}$ & 2.5 & Cook (1976) & 5 & 3 & 317 & Tribelet & Semi-sedentary \\
\hline Konkow & Sacramento Valley & River/Foothills & 8.4 & Cook (1976) & 10 & 4 & 256 & Complex Tribelet & Sedentary \\
\hline Maidu & Sacramento Valley & Foothills & 2.7 & Cook (1976) & 1 & 1 & 14 & Tribelet & Semi-sedentary \\
\hline Nisenan & Sacramento Valley & River & 8.4 & Cook (1976) & 16 & 7 & 431 & Complex Tribelet & Sedentary \\
\hline River Nomlaki & Sacramento Valley & River/Foothills & 3.0 & Cook (1976) & 4 & 3 & 31 & Complex Tribelet & Semi-sedentary \\
\hline Plains Miwok & Sacramento Valley & River/Prairie & 11.1 & Baumhoff (1963) & 36 & 24 & 2406 & Complex Tribelet & Sedentary \\
\hline River Patwin & Sacramento Valley & River/Prairie & 8.4 & Cook (1976) & 9 & 7 & 344 & Complex Tribelet & Sedentary \\
\hline Southern Patwin & Sacramento Valley & River Delta & 8.4 & Cook (1976) & 23 & 11 & 1279 & Complex Tribelet & Sedentary \\
\hline $\begin{array}{l}\text { Northern } \\
\text { Valley Yokuts }\end{array}$ & San Joaquin Valley & River/Prairie & 10.7 & Baumhoff (1963) & 19 & 10 & 1222 & Chiefdom & Sedentary \\
\hline Wintu & Sacramento Valley & Foothills & 1.5 & Cook (1976) & 9 & 3 & 418 & Tribelet & Seasonally mobile \\
\hline Yana & Sacramento Valley & Foothills & 0.9 & Cook (1976) & 10 & 4 & 91 & Complex Tribelet & Seasonally mobile \\
\hline $\begin{array}{l}\text { Central Sierra } \\
\text { Miwok }\end{array}$ & Sierra Nevada & $\begin{array}{l}\text { Foothills/Oak-Pine } \\
\text { Forest }\end{array}$ & 0.7 & Baumhoff (1963) & 3 & 1 & 27 & Complex Tribelet & Seasonally mobile \\
\hline $\begin{array}{l}\text { Northern } \\
\quad \text { Sierra Miwok }\end{array}$ & Sierra Nevada & $\begin{array}{l}\text { Foothills/Oak-Pine } \\
\text { Forest }\end{array}$ & $1.0^{\mathrm{a}}$ & - & 15 & 2 & 360 & Complex Tribelet & Seasonally mobile \\
\hline $\begin{array}{l}\text { Southern } \\
\text { Sierra Miwok }\end{array}$ & Sierra Nevada & $\begin{array}{l}\text { Foothills/Oak-Pine } \\
\text { Forest }\end{array}$ & 1.4 & Baumhoff (1963) & 18 & 8 & 510 & Complex Tribelet & Seasonally mobile \\
\hline Total & & & & & 329 & 163 & 16,820 & & \\
\hline
\end{tabular}

a Estimate based on adjoining groups from Baumhoff (1963).

Population estimates have been a focus of much research over the years, and there is consensus that the highest concentrations of people were along the shores of the Sacramento and San Joaquin rivers where most authorities suggest densities between 8 and 11.1 people/square mile (Table 1) (Baumhoff, 1963; Cook, 1976). Estimated population densities for the less specialized groups in the San Francisco Bay area and elsewhere range between 2 and 4.3 people/square mile while the more mobile groups show $<2.0$ people/square mile. In contrast, the island Chumash had a population density of 16.4 (Johnson, 2010). As noted above, these groups were not bands but were organized into very small autonomous tribelets generally of 200-400 people. Leadership structure varied. Among the Coast Miwok, for example, each large village had its own chief whose authority was not hereditary, and whose ascent to the office was guided by the grooming of elderly females (Kelly, 1978:419). The Plains and Sierra Miwok, on the other hand, had tribelet chiefs, commonly male but occasionally female, whose authority did pass from generation to generation. Elsewhere, among the Costanoan and Yokuts there are historic and ethnographic accounts of political hierarchy (Hylkema, 2002; Jones and Ferneau, 2002). In all of these groups, kin relations within lineages and in some cases moieties were of equal if not greater importance than the power of leaders. Recently, Allen (2012) distinguished the central California groups with some signs of political complexity (e.g., ascribed leadership positions, incipient hierarchy) as "complex tribelets," from simple "tribelets" where such traits were absent. We generally follow this classification here. As a whole, however, the northern California tribelets contrast markedly with the welldescribed Chumash chiefdoms of the Santa Barbara Channel which featured clear hierarchical political structure as well as other traits of social complexity (see Arnold, 1992, 2001; Erlandson and Rick, 2002; Gamble, 2008; Glassow et al., 2007; Johnson, 1988; Kennett, 2005).

\section{Accounts of violence}

Historic accounts recorded in the journals and official reports of travelers, soldiers, militiamen, and missionaries, together with ethnographic oral histories collected early on in the 20th century by anthropologists and historians provide some details on the nature of tribal conflict in central California. In more than a few cases, these accounts reveal warfare tactics, weaponry, combatants, victims, and some of the underlying causes of violence. We focus on these reports to provide a composite narrative of some expected signatures of violence among the physical remains excavated from archaeological sites in these ethnolinguistic territories.

The practice of dismemberment and trophy-taking was first reported by colonizers and visitors to central California (e.g., Bryant, 1967; La Pérouse, 1786 in Margolin [1989]; Font, 1776 in Bolton [1930] and Taylor [1856]). Descriptions of this behavior were subsequently recorded in ethnographic summaries of warfare for the region (e.g., James and Graziani, 1975; Kroeber, 1925, 1932; Lambert, 2007b; McCorkle, 1978), including this description from the San Francisco Bay area: “...chiefs had little power except in wars during which slain foe were mutilated and whose severed heads were displayed. Some parts of the enemy were said to be eaten by the parents of the slayer" (Kroeber, 1925:469).

Combat weaponry and eyewitness accounts of violence that resulted in blunt force cranial injuries caused by rocks, sling stones, and clubs are specifically discussed for the Costanoan, Maidu, Miwok, Nisenan, Patwin, Wappo, Wintu, Yana, and Yokuts, in both historic accounts (e.g., Bledsoe, 1885; Perkins 1850 in Morgan and Scobie [1964]; Powers, 1877; Savage 1851 in Bunnell [1911]; Yount 1855 in Camp [1966]) and oral histories provided by Native American informants (e.g., Beals, 1933; Driver, 1936; DuBois, 1935; Jewell, 1987; Kroeber, 1925). Likewise, specifics of sharp 
force/projectile trauma (i.e., projectile points embedded in bone and cutmarks) caused by thrusting-spears, knives, and arrows, are also present for all tribal groups from both historic accounts (e.g., Borthwick 1851 in Kephart [1917], Mooney, 1890; Palóu, 1774, 1776) and ethnographic sources (e.g., Barrett and Gifford, 1933; Cook, 1967; Gayton, 1948; Kroeber, 1925; Latta, 1949; Voegelin, 1938). Historic and ethnographic accounts of violence are in many cases sufficiently detailed to provide specifics of targeted elements or wound location on the body.

Strategic warfare tactics such as ambush, line-firing, the use of fire, defensive bulwarks and personal body armor in which these weapons were most commonly used are detailed to varying degrees in both historic accounts and ethnographies (e.g., Fages 1775 in Priestley [1937]; Goldschmidt, 1976; Goldschmidt et al., 1939; Gray, 1993; Kroeber, 1908; Lowie, 1939; Merriam, 1955; Voegelin, 1942).

The historic record also provides information on the demographics of combatants and non-combatants and the disposition of enemy tribal members following battle. Descriptions of warriors during these violent encounters are overwhelmingly male; however, some historic records also document females as active combatants. Bay Miwok women fought side by side with their men in a defensive battle against Sergeant Pedro Amador in July of 1797. In the official report to Spanish Governor Diego de Borica, Amador wrote: "There were only about fifty Indian men and women engaging us, but these had their quivers full, and had many more bundles of them in reserve by their sides" (Amador 1797 in McCarthy [1958:65]). In a Gold Rush era account, southern Sierra Miwok women also took up arms in defense of themselves and their tribe: "One of our men was going to finish her with his knife, but seeing it was a woman he left her. No sooner had he gone than she picked up a bow and lodged three arrows in another man. I believe she was not touched after that" (Palmer 1851 in Bunnell [1911:33]). Historic eyewitness accounts document that Costanoan, Southern Patwin, Plains Miwok and Yokut women were also participants in combat and had combat support roles during battlefield skirmishes with neighboring tribes and colonizers (e.g., Fages 1775 in Priestly [1937]). A native informant recounting war stories in the 1930s passed down as part of his tribal heritage said of Yuki women fighting the Nomlaki: "Women who had lost their men were even more terrible as fighters than the men" (Goldschmidt et al., 1939:143). Collectively these reports suggest that, at a minimum, during times of trouble women warriors functioned as auxiliary combatants in central California. Furthermore, these accounts depart from the generalization that females were always mere spoils of war, and passive victims of male-dominated violence as portrayed in most ethnographies under discussion here (e.g., Aginsky, 1943; Beals, 1933; Driver, 1936; DuBois, 1935; Gifford and Klimek, 1937; Gifford and Kroeber, 1937; Goldschmidt et al., 1939; Kroeber, 1925, 1932; Merriam, 1955).

The role and disposition of children during warfare also varies greatly between historic and ethnographic accounts. Many if not the majority of ethnographic accounts include descriptions of children being kidnapped and/or killed by enemy combatants during tribal conflict (e.g., Beals, 1933; Driver, 1936; DuBois, 1935; Goldschmidt et al., 1939; Kroeber, 1925, 1932; Merriam, 1955). However, historic eyewitness accounts rarely featured children as targets or victims of violent tribal encounters (e.g., Fages, 1775 in Priestly [1937], Kroeber, 1908; Palóu, 1776 in Bolton [1926]). As pointed out by Goldschmidt and co-workers (1939) native informants relating warfare accounts often depicted the enemy tribe as committing the most egregious acts. This almost certainly explains the disparity between historic eyewitness accounts of children as victims and the ethnographic record. It is likely that not until the colonizers of California (i.e., Spanish, Mexican, and American) started conducting large scale, organized, and militaristic punitive raids against the indigenous people of central California that death among children in battlefield skirmishes and village massacres became widespread.

\section{Materials and methods}

Our primary source of information is the central California bioarchaeological database (CCBD) compiled by the first author over the last thirteen years. The CCBD is a meta-database containing information on 16,820 individuals compiled from published and unpublished archaeological site reports, osteological appendices, burial records, and NAGPRA inventories housed at regional repositories. In most cases, these reports constitute the only information available on cemetery populations as human remains in California are now rarely, if ever, submitted to curatorial facilities but instead are re-buried following the protocols of state and federal law, and the wishes of tribal descendants. The cemetery sites discussed herein are within the ethnographic territories of 19 tribal groups in central California (Table 1). Results from earlier versions of the CCBD have been reported previously (Jones and Schwitalla, 2008; Schwitalla, 2010, 2013; Schwitalla and Jones, 2012) including the study by Andrushko et al. (2010) on trophy-taking.

None of the studies included in the CCBD were specifically undertaken for the purposes of the current paper, although one of us (Wiberg) has analyzed and reported many of the burials ( $n=1926)$ in the CCBD over the past 35 years as part of cultural resource management (CRM) projects. CRM investigations, which have become the primary source of burial information in the last 30 years, have generally included physical anthropologists as part of field and post-field research teams. The osteological reports resulting from these investigations are detailed, accurate, and accessible from regional archaeological clearinghouses. This is a key point as determination of age and sex as well as the identification of trauma and pathological conditions require an intimate knowledge of osteology and skeletal morphology. Details on the sources of information for sites that produced evidence for violence including the name and qualifications of the principal osteologist who evaluated the remains are provided in Appendix A. Additional information is available from Schwitalla (2010, 2013) and Schwitalla and Jones (2012).

The CCBD includes information on the individual age, sex, mortuary characteristics, pathological conditions, missing and detached body parts, modified human bone, antemortem and perimortem traumatic injuries, degree and type of taphonomic disturbances, and temporal phase assignments based on chronological markers. Unfortunately, information available for some individual burial profiles was incomplete due to limited or absent osteological and/or chronological data. Furthermore, in some cases, the appropriate knowledge was not available at the field site and/ or not all skeletal elements were present or recovered so age and sex determinations are not available for all burials. In the case of cemetery populations that are currently curated in museums and government repositories, recognition of various skeletal pathological conditions, age, and sex determinations have in many instances been made during subsequent research or during the course of NAGPRA inventories completed in the last two decades. Therefore, only records housed at government repositories or available from CRM mitigation reports that were complete enough to definitively document the presence or absence of trophy-taking/ dismemberment, sharp force/projectile trauma, and blunt force craniofacial trauma were used to develop statistics for the current paper.

Within the CCBD, skeletal data were aggregated to include three categories for sex: male, female, and indeterminate (due to lack of 
skeletal indicators). Only individuals that were late adolescents or older were included in this study (i.e., 12 years of age or older). Age estimates provided in the various reports were placed into one of five categories: adolescent (12-18), young adult (18-25), middle adult (25-45), old adult (45+), or simply adult (18+, given a lack of more precise age markers).

Data were treated separately for each analysis as appropriate for that skeletal indicator of violence. The analysis and discussion of trophy-taking and dismemberment follows Andrushko et al. (2010) in that the data represent crude prevalence rates for this form of violence, such that all adult individuals, late adolescents for whom sex could be determined, and relatively complete skeletons for which limited age and sex data were available are included in analyses $(n=12,603)$. A study at this level has the potential to lower overall frequencies by enlarging sample size. However, this analytical approach was chosen because trophytaking and dismemberment can be manifest almost anywhere on the skeleton; therefore, a targeted approach to preservation and prevalence rates per element would require extensive reporting that is beyond the scope of this paper. Here, we attempted instead to capture an overall picture of this form of violent behavior through an all-inclusive analysis of individuals. Moreover, this type of violent behavior is frequently reported in this way so our approach here facilitates direct comparison of datasets. The study of craniofacial trauma only included late adolescent to adult individuals with all elements of the skull present (e.g., parietals, frontal, maxillary, mandible, and occipital) at least in partial form. This culling of the data greatly reduced our sample size, down to 6202 individuals from the original 16,820. Treating the data in this way has the potential to inflate frequencies through sample size reduction; however, this method was preferred such that a more accurate picture of craniofacial trauma could be captured, as it is impossible to evaluate individuals for craniofacial trauma if these elements are largely absent. Sharp force/projectile trauma analyses included individuals that were represented by a majority of skeletal elements (i.e., $\geqslant 70 \%$ of the skeleton present). This analysis also included targeted elements commonly associated with indications of violence (e.g., skull, long bones, manubrium, ribs, vertebral column, pelvic girdle). As sharp force and projectile injuries have a more patterned appearance in the skeleton, this approach was chosen to obtain a more precise representation of the nature and prevalence of violent behaviors. Again, selecting for only certain individuals based on preservation greatly reduced sample size, down to only 6278 individuals. To determine if differences were significant, data were analyzed using a chi-square test. All statistical analyses were done with the software package SPSS 19.0.

Temporal assignments were based on artifact associations, obsidian-hydration values, radiocarbon dates, and stratigraphic superposition at sites with delineated temporal components. While Lambert's (1994) study included some burials from the Santa Barbara area that dated as far back as 6600 cal B.C., the central California skeletal remains included in our database all post-date cal. 3050 B.C. due to the fact that only a handful of older skeletons has been uncovered from central California. The paucity of early Holocene burials seems to be a product of poor site visibility (including the likelihood of very deeply buried contexts) and unfavorable organic preservation. Archaeological sites were divided into six main time periods based on the recent updates to the central California Taxonomic System (CCTS) made by Groza (2002), Hughes and Milliken (2007) and Schwitalla (2013). These time periods are: Early 3050-500 B.C., Early Middle 500 B.C.-A.D. 420, Late Middle A.D. 420-1010, Middle-Late Transition A.D. 10101390, Late Prehistoric A.D. 1390-1720, and Protohistoric/Historic A.D. 1720-1899. Owing to regional variation in cultural patterns, these periods are similar to but not fully synchronous with those used in the Santa Barbara Channel.

Certainly a meta-database of this size also presented many challenges, including variation in methodology among researchers, missing information, inter-observer error, transcription error during data entry, and accounting for the level of experience of individual analysts. In an attempt to mitigate such errors, the CCBD is continually updated and data are re-checked for accuracy. Moreover, age and sex determinations made 50 years ago from skeletal collections that are still curated and available for study have in some instances been found to be in error based on subsequent analysis. As this new information becomes available through thesis and dissertation research, or mandated NAGPRA inventories, adjustments have been made to the CCBD. The CCBD represents over one hundred years of scientific inquiry by several hundred researchers, and while interest, focus, and methods have evolved within biological anthropology over the years, the sheer volume of the database and its cumulative nature are its strengths. While there are certainly limitations to the types of research questions that can be answered with a data set of this type, it is nonetheless a starting point and has already provided macro-view reconstructions for some general health and behavior trends among the indigenous populations that lived in central California (e.g. Andrushko et al., 2010; Jones and Schwitalla, 2008; Schwitalla, 2013; Schwitalla and Jones, 2012).

\section{Results}

Among the 16,820 burials in the current database, 11,896 (70.7\%) represented adults (greater than or equal to 18 years old at the time of death) with 4179 adult males, 3996 adult females, and 3721 adults of indeterminate or undetermined sex (Table 2). A total of 3841 individuals (22.8\%) were sub-adults of indeterminate sex, and $278(1.7 \%)$ were older subadults/late adolescents for whom sex could be determined. A total of 805 (4.8\%) burials had neither sex nor age determinations. Of the 329 sites in the database, a total of 163 (49.5\%) showed evidence for at least one of the three forms of violence that we highlight here: trophy-taking/dismemberment was represented at 37 (11.2\%) sites; blunt force craniofacial trauma at $89(27.1 \%)$ sites, and sharp force/projectile trauma at 127 (38.6\%) sites (see Appendix A). The following is a more detailed description of the findings for each of these forms of violence with particular emphasis on skeletons for which sex determinations were available.

\section{Trophy-taking and dismemberment}

Dismemberment represents a process of body part removal typified by cutmarks surrounding joint surfaces (Hurlbut, 2000) whereas trophy-taking is the practice of dismembering and exhibiting different body parts to display as if a prize or trophy. This practice extends deep into the prehistoric period and is found throughout the New World (Chacon and Dye, 2007). Archaeological evidence of trophy-taking includes the presence of bone with cutmarks proximal to a missing body part in an undisturbed burial context (Fig. 3), the presence of removed body parts (such as modified limbs with no associated bone), and evidence of scalping (circumferential cutmarks of the cranial vault), and/or decapitation (Smith, 1997).

Because the bulk of the bioarchaeological evidence indicative of this form of violence was thoroughly reported for central California by Andrushko et al. (2010) using an earlier (ca. 2006) version of the current database, our objective here is simply to update the previous tally with finds made in the intervening 
Table 2

Demographic breakdown of burials in the central California bioarchaeological database by ethnographic territory.

\begin{tabular}{|c|c|c|c|c|c|c|c|}
\hline $\begin{array}{l}\text { Ethnographic } \\
\text { territory }\end{array}$ & $\begin{array}{l}\text { Adult } \\
\text { female }\end{array}$ & $\begin{array}{l}\text { Adult } \\
\text { male }\end{array}$ & $\begin{array}{l}\text { Adult indeterminate } \\
\text { (Sex) }\end{array}$ & $\begin{array}{l}\text { Sub-adult indeterminate } \\
\text { (Sex) }\end{array}$ & $\begin{array}{l}\text { Sub-adult determinate } \\
\text { (Sex) }\end{array}$ & $\begin{array}{l}\text { Indeterminate for age and } \\
\text { sex }\end{array}$ & Total \\
\hline Bay Miwok & 375 & 370 & 624 & 276 & 14 & 22 & 1681 \\
\hline Coast Miwok & 76 & 119 & 73 & 76 & 5 & 30 & 379 \\
\hline Costanoan & 1659 & 1794 & 1103 & 1542 & 147 & 230 & 6475 \\
\hline Wappo & 2 & 11 & 0 & 3 & 0 & 10 & 26 \\
\hline Hill Nomlaki & 128 & 123 & 47 & 236 & 4 & 15 & 553 \\
\hline Hill Patwin & 42 & 36 & 135 & 97 & 0 & 7 & 317 \\
\hline Konkow & 55 & 50 & 85 & 52 & 8 & 6 & 256 \\
\hline Maidu & 4 & 6 & 0 & 4 & 0 & 0 & 14 \\
\hline Nisenan & 90 & 69 & 104 & 67 & 7 & 94 & 431 \\
\hline River Nomlaki & 9 & 8 & 8 & 5 & 1 & 0 & 31 \\
\hline Plains Miwok & 564 & 582 & 650 & 467 & 32 & 111 & 2406 \\
\hline River Patwin & 83 & 107 & 48 & 83 & 9 & 14 & 344 \\
\hline Southern Patwin & 321 & 370 & 171 & 292 & 24 & 101 & 1279 \\
\hline $\begin{array}{l}\text { Northern Valley } \\
\text { Yokuts }\end{array}$ & 257 & 282 & 320 & 288 & 15 & 60 & 1222 \\
\hline Wintu & 44 & 52 & 142 & 95 & 0 & 85 & 418 \\
\hline Yana & 27 & 24 & 15 & 23 & 2 & 0 & 91 \\
\hline $\begin{array}{l}\text { Central Sierra } \\
\text { Miwok }\end{array}$ & 4 & 3 & 14 & 6 & 0 & 0 & 27 \\
\hline $\begin{array}{l}\text { Northern Sierra } \\
\text { Miwok }\end{array}$ & 117 & 65 & 77 & 80 & 7 & 14 & 360 \\
\hline $\begin{array}{l}\text { Southern Sierra } \\
\text { Miwok }\end{array}$ & 139 & 108 & 105 & 149 & 3 & 6 & 510 \\
\hline Total & 3996 & 4179 & 3721 & 3841 & 278 & 805 & 16,820 \\
\hline
\end{tabular}

years. A total of 11 new instances of trophy-taking and/or dismemberment have been discovered from eight additional sites (Appendix B) bringing the central California total to 87 cases from 37 sites in the territories of 13 ethnographic groups (Fig. 4a, Table 3). The largest number of cases from any single site remains $5.8 \%$ (14/243) from CA-SCL-674 (Grady et al., 2001). Andrushko et al. (2010) argued that this form of violence was temporally and spatially ubiquitous in central California, but such an inference is equivocal; 292 out of the 329 sites $(88.8 \%)$ showed no evidence for dismemberment or trophy-taking and it was absent from six ethnographic territories although some are represented by small samples. The highest frequency was $2.2 \%$ (6/269) in River Patwin territory followed by $1.3 \%$ (63/4815) in ethnographic Costanoan territory in the southern San Francisco Bay area. The overall crude prevalence for the entire central California sample is $0.7 \%(87 / 12,603)$. Even this relatively low frequency contrasts with ethnographic Chumash territory of southern California where Lambert (1994) did not report any evidence for trophytaking/dismemberment in her study of 1744 burials although her focus was exclusively on the narrower category of scalping rather than trophy-taking.

Our slightly enlarged dataset generally exhibits the same previously reported demographic patterns for trophy-taking and dismemberment cases; of the 79 individuals for whom sex could be determined, 61 (77.2\%) were males and 18 (22.8\%) were females, suggesting that males were three times more likely to be subjected to this type of violence than females.

Temporal patterning is also consistent with trends identified previously by Andrushko et al. (2010). The highest frequency of this form of violence was during the Early Middle Period $(500 \mathrm{cal}$ B.C.-cal A.D. 420) when the frequency for males was $4.2 \%$ (33/ 972), representing a substantial increase from the preceding Early Period (1 male among 421 burials or $0.2 \%$ ) (Table 4). Following the spike during the Early Middle Period, the frequency of this form of violence generally declined; only two burials from the Protohistoric/Historic Period (A.D. 1720-1899) showed this form of trauma in a sample of 841 .

Although not a main focus of our current research we must also mention human bone artifacts and modified human elements that have been recovered from central California and considered

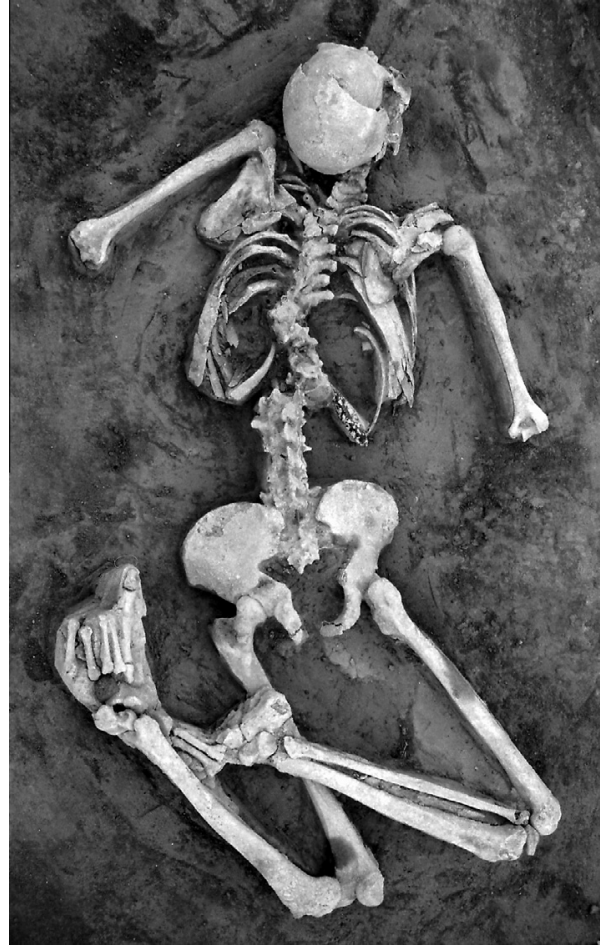

Fig. 3. Example of trophy-taking from central California: Burial 37, CA-SCL-478 (500-210 cal B.C.) (Photograph by Randy Wiberg).

previously as evidence for violence (Andrushko et al., 2010). A total of 30 such artifacts have been documented from 16 of the 329 sites in the current database (Appendix C). All but three were associated with human burials, eight of which were male and five were female. The specific elements include nine modified radii, eight femora, seven ulnae, four calvaria, three tibiae, two fibulae, and one rib. Formal artifacts as defined by the typology of non-human 

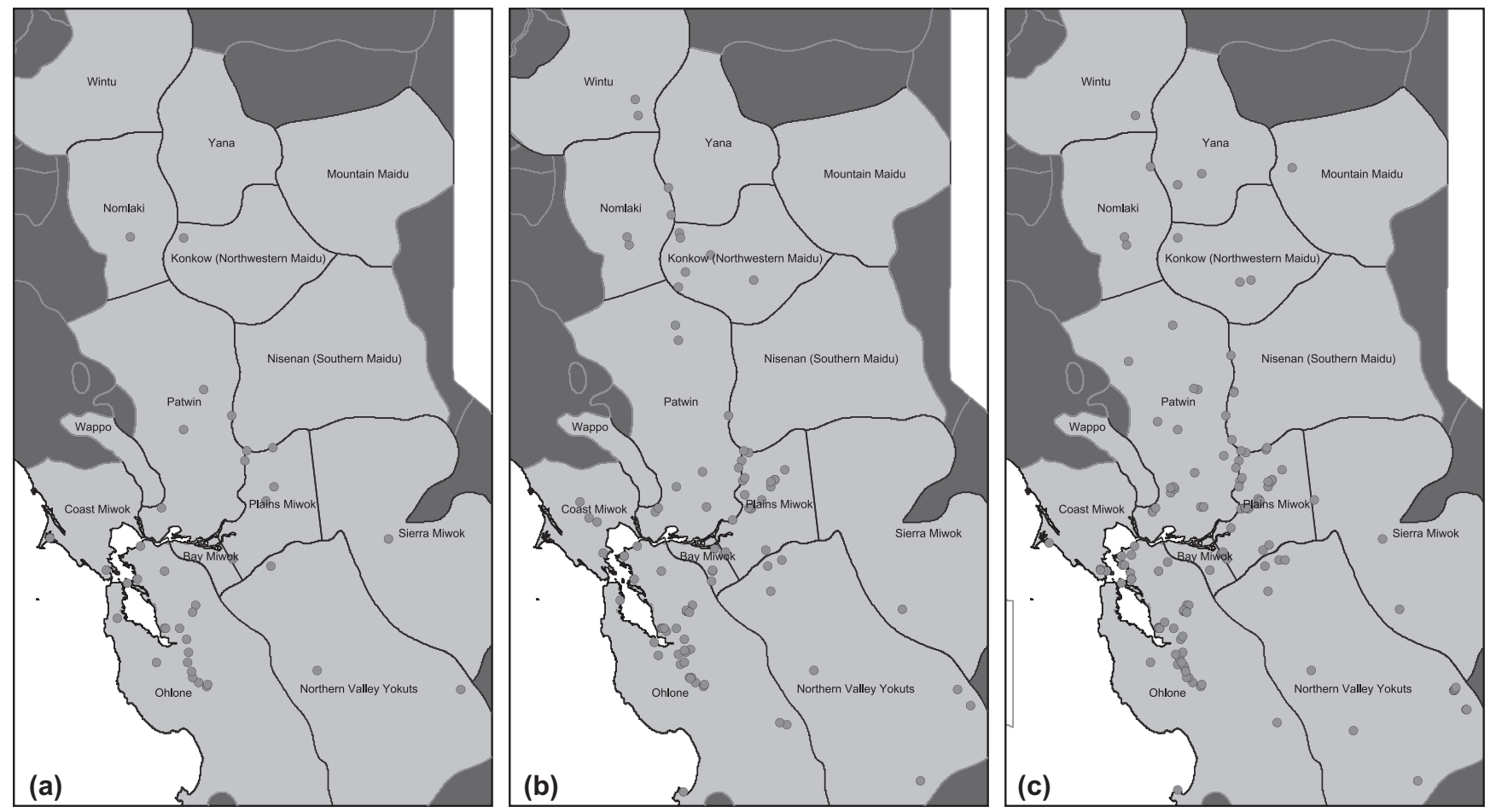

Fig. 4. Sites with skeletal evidence for violence in central California: (a) Trophy-taking; (b) Blunt force cranial trauma; (c) Sharp force cranial trauma.

Table 3

Summary of trophy-taking and dismemberment by ethnographic territory.

\begin{tabular}{|c|c|c|c|c|c|c|c|c|}
\hline \multirow[t]{2}{*}{ Territory } & \multicolumn{2}{|l|}{ Female } & \multicolumn{2}{|l|}{ Male } & \multicolumn{2}{|c|}{ Indeterminate } & \multicolumn{2}{|l|}{ Total } \\
\hline & $N$ & $\%$ & $N$ & $\%$ & $N$ & $\%$ & $N$ & $\%$ \\
\hline Bay Miwok & $0 / 381$ & 0.0 & $0 / 378$ & 0.0 & $1 / 622$ & 0.16 & $1 / 1381$ & 0.07 \\
\hline Coast Wiwok & $0 / 79$ & 0.0 & $2 / 119$ & 1.7 & $0 / 85$ & 0.00 & $2 / 283$ & 0.71 \\
\hline Costanoan & $13 / 1692$ & 0.8 & $47 / 1804$ & 2.6 & $3 / 1319$ & 0.23 & $63 / 4815$ & 1.31 \\
\hline Wappo & $0 / 2$ & 0.0 & $0 / 11$ & 0.0 & $0 / 0$ & 0.00 & $0 / 13$ & 0.00 \\
\hline Hill Nomlaki & $1 / 131$ & 0.8 & $0 / 124$ & 0.0 & $0 / 77$ & 0.00 & $1 / 332$ & 0.30 \\
\hline Hill Patwin & $0 / 42$ & 0.0 & $0 / 36$ & 0.0 & $1 / 112$ & 0.89 & $1 / 190$ & 0.53 \\
\hline Konkow & $0 / 62$ & 0.0 & $0 / 51$ & 0.0 & $0 / 108$ & 0.00 & $0 / 221$ & 0.00 \\
\hline Maidu & $0 / 4$ & 0.0 & $0 / 6$ & 0.0 & $0 / 0$ & 0.00 & $0 / 10$ & 0.00 \\
\hline Nisenan & $0 / 95$ & 0.0 & $1 / 72$ & 1.4 & $0 / 112$ & 0.00 & $1 / 279$ & 0.36 \\
\hline River Nomlaki & $0 / 10$ & 0.0 & $0 / 8$ & 0.0 & $0 / 8$ & 0.00 & $0 / 26$ & 0.00 \\
\hline Plains Miwok & $1 / 584$ & 0.2 & $0 / 594$ & 0.0 & $2 / 745$ & 0.27 & $3 / 1923$ & 0.16 \\
\hline River Patwin & $1 / 88$ & 1.1 & $5 / 111$ & 4.5 & $0 / 70$ & 0.00 & $6 / 269$ & 2.23 \\
\hline Southern Patwin & $0 / 355$ & 0.0 & $1 / 380$ & 0.3 & $0 / 211$ & 0.00 & $1 / 946$ & 0.12 \\
\hline Northern Valley Yokuts & $1 / 264$ & 1.9 & $2 / 290$ & 0.7 & $0 / 383$ & 0.00 & $3 / 937$ & 0.32 \\
\hline Wintu & $0 / 44$ & 0.0 & $0 / 52$ & 0.0 & $0 / 154$ & 0.00 & $0 / 250$ & 0.00 \\
\hline Yana & $0 / 28$ & 0.0 & $1 / 25$ & 4.0 & $0 / 15$ & 0.00 & $1 / 68$ & 1.47 \\
\hline Central Sierra Miwok & $0 / 4$ & 0.0 & $0 / 3$ & 0.0 & $0 / 15$ & 0.00 & $0 / 22$ & 0.00 \\
\hline Northern Sierra Miwok & $1 / 121$ & 0.8 & $1 / 67$ & 1.5 & $1 / 76$ & 1.31 & $3 / 264$ & 1.14 \\
\hline Southern Sierra Miwok & $0 / 142$ & 0.0 & $1 / 108$ & 0.9 & $0 / 124$ & 0.00 & $1 / 374$ & 0.27 \\
\hline Total & $18 / 4128$ & 0.4 & $61 / 4239$ & 1.4 & $8 / 4236$ & 0.18 & $87 / 12,603$ & 0.69 \\
\hline
\end{tabular}

bone implements for central California (Gifford, 1940) included six femur daggers, four calvarium containers or skull bowls (Fig. 5), one radius whistle, one tibia whistle, one femur whistle, one femur atlatl, one fibula pin, and one fibula dagger. The remaining artifacts exhibited various combinations of drilling, polishing, grinding, and/or working. Spatially, these artifacts were more common in the San Francisco Bay area with 11 (36.7\%), found in ethnographic Costanoan territory, eight (26.7\%) in Bay Miwok territory, and six (20\%) in Plains Miwok territory. The temporal distribution of these modified elements shows highest frequency in the Early Period ( $n=14 ; 46.7 \%$ ), followed by the Early Middle Period $(n=12 ; 40 \%)$, with only four (13.3\%) examples recovered from contexts post-dating cal A.D. 420.

\section{Blunt force craniofacial trauma}

Blunt force trauma occurs when a large surface area is impacted at low velocity leading to breakage of skeletal elements (Fig. 6). This type of trauma can be inflicted with any number of objects (e.g. sticks, clubs, fists, rocks), or can be the result of falls or car accidents (Galloway, 1999; Komar and Buikstra, 2008). Here we focus on blunt force trauma to the skull as an indicator of violent behavior. While it is possible that some of these injuries were sustained through falls or accidents, we focus on various patterns of craniofacial trauma indicative of intentional injuries or interpersonal violence as previously outlined by Walker (1989) for southern California. 
Table 4

Relative frequency of trophy-taking/dismemberment over time in central California.

\begin{tabular}{|c|c|c|c|c|c|c|c|c|}
\hline \multirow[t]{2}{*}{ Time period } & \multicolumn{2}{|l|}{ Females } & \multicolumn{2}{|l|}{ Males } & \multicolumn{2}{|c|}{ Indeterminate } & \multicolumn{2}{|l|}{ Total } \\
\hline & $N$ & $\%$ & $N$ & $\%$ & $N$ & $\%$ & $N$ & $\%$ \\
\hline 3050-500 В.С. & $0 / 392$ & 0.0 & $1 / 421$ & 0.2 & $1 / 600$ & 0.2 & $2 / 1413$ & 0.1 \\
\hline 500 B.C.-A.D. 420 & $7 / 675$ & 1.0 & $33 / 792$ & 4.2 & $1 / 726$ & 0.1 & $41 / 2193$ & 1.9 \\
\hline A.D. $420-1010$ & $4 / 1213$ & 0.3 & $12 / 1186$ & 1.0 & $2 / 1059$ & 0.2 & $18 / 3458$ & 0.5 \\
\hline A.D. $1010-1390$ & $4 / 1047$ & 0.4 & $10 / 1089$ & 0.9 & 3/908 & 0.3 & $17 / 3044$ & 0.6 \\
\hline A.D. $1390-1720$ & $1 / 535$ & 0.2 & $5 / 508$ & 0.9 & $1 / 611$ & 0.2 & $7 / 1654$ & 0.4 \\
\hline A.D. $1720-1899$ & $2 / 266$ & 0.8 & $0 / 243$ & 0.0 & $0 / 332$ & 0.0 & $2 / 841$ & 0.2 \\
\hline Totals & $18 / 4128$ & 0.4 & $61 / 4239$ & 1.4 & $8 / 4236$ & 0.2 & $87 / 12,603$ & 0.7 \\
\hline
\end{tabular}

Blunt force trauma to the head may result in depressed or simple linear fractures and more severe impacts can lead to comminution (Lovell, 1997). In this study, these fracture types were treated separately (depressed (Fig. 6), linear, and comminuted), and were further differentiated as to time of occurrence, either antemortem or perimortem. Therefore a total of six fracture types of the skull were recorded. The location of the injury was also noted, as part of the cranial vault (frontal, temporal, parietal, occipital), the face, the nasal bone, or the mandible. This analysis included a subset of the skeletons available from the CCBD; only those individuals with a documented presence of craniofacial elements were included so that presence and absence could be confidently determined (true prevalence).

Evidence for blunt force craniofacial trauma was identified in a total of 264 burials in the database, representing 13 of the 19 ethnographic territories (Appendix A, Fig. 4b). Of all individuals with observable crania that could be reliably sexed, $4.0 \%$ of females (103/2580) and $5.5 \%$ of males $(141 / 2557)$ showed evidence for blunt force craniofacial trauma, these differences are statistically significant $\left(\chi^{2}=6.875, p=0.01\right)$. Evaluation of the relative frequency of trauma by skull location shows no significant difference between the sexes, except in the frontal bone, where males show blunt force trauma at much higher rates (Table 5). The most commonly affected areas are the frontal and parietal bones. The remainder of the skull exhibits blunt force trauma at much lower frequencies.

In a consideration of age, older individuals of both sexes show higher rates of blunt force craniofacial trauma (Table 6). The occurrence of this type of trauma among males peaks during the middle adult period; whereas, females show increasingly higher rates of craniofacial trauma with age. A statistically significant difference is only seen between males and females that are young adults $\left(\chi^{2}=11.97, p=0.01\right)$. Additionally, significant differences among age groups are found for males, females, and in a consideration of all individuals (regardless of sex) (Table 5).

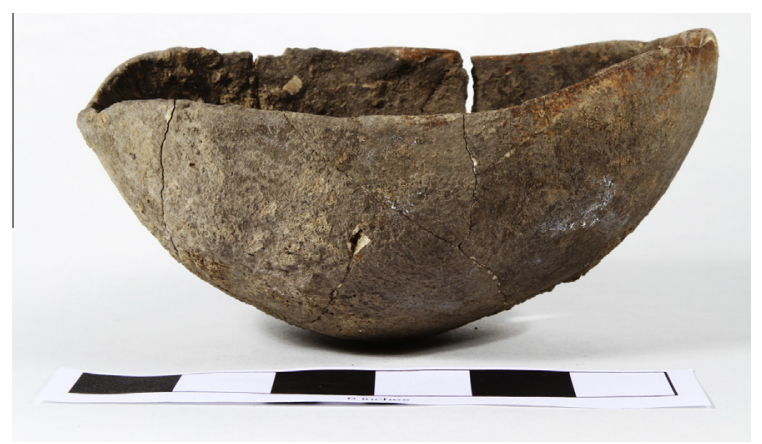

Fig. 5. Example of formal artifact made from human bone: partial calvarium or skull bowl from CA-CCO-548 (Photograph by Al Schwitalla).

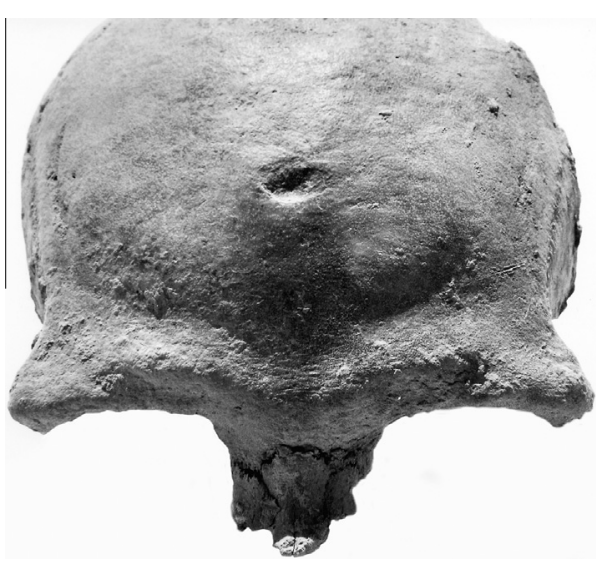

Fig. 6. Example of antemortem depressed blunt force cranial trauma, Burial 37, CASCL-478 (500-210 cal B.C.) (Photograph by Randy Wiberg).

The frequency of blunt force craniofacial trauma remained essentially unchanged for the first five time periods represented in the sample (3050 B.C.-A.D. 1720), but rose markedly during the Protohistoric/Historic Period (A.D. 1720-1899) (Table 7). Analysis by sex also shows that frequencies are comparable through time for each sex with major changes after A.D. 1720 when there was nearly a fourfold increase in the frequency of this form of violence among males and a doubling among females compared to the previous period. This suggests an overall increase in violence during the Protohistoric/Post-contact period that disproportionately affected males.

The spatial distribution of blunt force craniofacial trauma by ethnographic territory also shows variation (Table 8), some of which is exaggerated by small sample size for certain ethnographic territories. Restricting comparisons to those areas where at least 100 burials have been recovered, the highest frequency is among the Northern Valley Yokuts (16/286 individuals or 5.6\%), followed by the Plains Miwok (29/538 or 5.4\%), and Costanoan (125/3164 or $4.0 \%)$. These groups all shared boundaries. On a regional basis there is strong variation with the Sierra Nevada foothills which exhibit extremely low frequencies of blunt force craniofacial trauma (2/397 or $0.5 \%)$ with higher frequencies in the San Francisco Bay area $(130 / 3456$ or $3.8 \%)$ and Central Valley (132/2349 or $5.6 \%)$ (Table 9).

In general, the frequency of this type of trauma is considerably lower than the values reported by Walker (1989) for the Santa Barbara Channel, where skulls from the northern Channel Islands showed a combined mean frequency of $18.6 \%$ (Walker, 1989:313). Chronological variation is also apparent between the regions as the peak in this form of violence in the Santa Barbara area was during the Early Middle Period (1490 cal B.C. to cal A.D. 580), which is considerably earlier than in central California where 
Table 5

Individuals with evidence of blunt force craniofacial trauma by sex and location on the skull.

\begin{tabular}{|c|c|c|c|c|c|c|c|c|c|c|}
\hline \multirow[t]{2}{*}{ Location } & \multicolumn{2}{|l|}{ Female } & \multicolumn{2}{|l|}{ Male } & \multicolumn{2}{|c|}{ Indeterminate } & \multicolumn{2}{|l|}{ Total } & \multicolumn{2}{|c|}{ Chi-square $^{\mathrm{a}}$} \\
\hline & $N / 2580$ & $\%$ & $N / 2557$ & $\%$ & $N / 1065$ & $\%$ & $N / 6202$ & $\%$ & $\chi^{2}$ & $p$-Value \\
\hline Frontal & 33 & 1.3 & 53 & 2.1 & 8 & 0.8 & 93 & 1.5 & 4.49 & 0.03 \\
\hline Parietal & 45 & 1.7 & 50 & 2.0 & 13 & 1.2 & 108 & 1.7 & 0.31 & 0.58 \\
\hline Occipital & 7 & 0.3 & 8 & 0.3 & 1 & 0.1 & 16 & 0.3 & 0.08 & 0.78 \\
\hline Temporal & 7 & 0.3 & 8 & 0.3 & 0 & 0 & 15 & 0.2 & 0.08 & 0.78 \\
\hline Facial & 3 & 0.1 & 3 & 0.1 & 0 & 0 & 6 & 0.1 & 0.00 & 0.99 \\
\hline Nasal & 9 & 0.3 & 13 & 0.5 & 1 & 0.1 & 23 & 0.4 & 0.77 & 0.38 \\
\hline Mandible & 7 & 0.3 & 6 & 0.2 & 0 & 0 & 13 & 0.2 & 0.07 & 0.79 \\
\hline
\end{tabular}

${ }^{a}$ Chi-square is between males and females for each location.

Table 6

Distribution of blunt force craniofacial trauma by age.

\begin{tabular}{|c|c|c|c|c|c|c|c|c|c|c|}
\hline \multirow[t]{2}{*}{ Age } & \multicolumn{2}{|l|}{$\underline{\text { Female }}$} & \multicolumn{2}{|l|}{ Male } & \multicolumn{2}{|c|}{ Indeterminate } & \multicolumn{2}{|l|}{ Total } & \multicolumn{2}{|c|}{ Chi-square $^{a}$} \\
\hline & $N$ & $\%$ & $N$ & $\%$ & $N$ & $\%$ & $N$ & $\%$ & $\chi^{2}$ & $p$-Value \\
\hline Adolescent (12-18) & $2 / 91$ & 2.2 & $1 / 51$ & 2.0 & $3 / 226$ & 1.3 & $6 / 368$ & 1.6 & 0.01 & 0.93 \\
\hline Young adult (18-35) & $29 / 1089$ & 2.7 & $71 / 1227$ & 5.8 & $4 / 290$ & 1.4 & $104 / 2606$ & 4.0 & 13.62 & 0.00 \\
\hline Middle adult (35-45) & $25 / 485$ & 5.2 & $39 / 519$ & 7.5 & $2 / 51$ & 3.9 & $66 / 1055$ & 6.3 & 2.88 & 0.24 \\
\hline Old adult $(45+)$ & $38 / 513$ & 7.4 & $18 / 368$ & 4.9 & $2 / 66$ & 3.0 & $58 / 947$ & 6.1 & 2.28 & 0.13 \\
\hline Total & $94 / 2178$ & & $129 / 2165$ & & $11 / 633$ & & $234 / 4976$ & & & \\
\hline$\chi^{2}$ & 20.89 & & 4.50 & & 2.51 & & 21.24 & & & \\
\hline$p$-Value & $\leq 0.01$ & & 0.211 & & 0.47 & & $\leq 0.01$ & & & \\
\hline
\end{tabular}

a Chi-square is between males and females for each age group.

the apex is apparent during the Protohistoric/Historic Period (A.D. 1720-1899).

\section{Sharp force/projectile trauma}

Sharp force trauma results from a foreign object applying forces on a narrow surface of bone (Fig. 7). The object therefore also needs to be narrow, such as a knife, saw, or other type of cutting implement (Galloway, 1999) and the force needs to be sufficient enough that it will penetrate and scar the skeletal tissue. Cutting actions associated with sharp force trauma generally include stabbing, slashing, or chopping with a sharp object (Komar and Buikstra, 2008). Evidence of sharp force trauma is generally present in cases of dismemberment and trophy-taking; however, other forms of sharp force trauma also exist as a result of violent encounters. Therefore, sharp force trauma is dealt with separately here as an additional type of evidence for violent behavior in the archaeological record as indicated by cutmarks, indentations, perforations, or holes in bone that clearly were the result of sharp force penetration. We also include in this analysis evidence for projectile point trauma identified by the occurrence of projectiles and/or their fragments embedded in bone (Fig. 7). These types of trauma can be equated to weapon wounds (Merbs, 1989), and as it can be difficult to tease apart sharp force/projectile trauma in the archaeological record, they are analyzed together here. For the current study, sharp force trauma was recorded on the basis of the presence of projectile point wounds on the skeleton, specifically the occurrence of projectiles and/or their fragments embedded in bone (Fig. 7), or indentations, perforations, or holes in bone that clearly were the result of sharp force penetration.

Evidence for sharp force/projectile trauma was identified in $7.4 \%$ (462/6278) of individuals for whom the skeleton was $>70 \%$ complete (Fig. 4c). This form of violence was significantly more common among males $(273 / 2553$ or $10.7 \%)$ than females (118/ 2594 or $\left.4.5 \% ; \chi^{2}=69.20, p<0.001\right)$. There is also a statistically significant difference between the age groups, indicating that this type of trauma occurred more often in younger individuals (Table 10). In every age group, except the youngest (adolescent) there is a statistically significant difference between males and females. In contrast to blunt force craniofacial trauma, sharp force/projectile trauma was more prevalent among females at a younger age including adolescence and early adulthood. Males showed much higher rates in young and middle adulthood, in much the same pattern as blunt force craniofacial trauma.

Table 7

Frequency of blunt force craniofacial trauma by time period.

\begin{tabular}{|c|c|c|c|c|c|c|c|c|c|c|}
\hline \multirow[t]{2}{*}{ Time period } & \multicolumn{2}{|l|}{ Female } & \multicolumn{2}{|l|}{ Male } & \multicolumn{2}{|c|}{ Indeterminate } & \multicolumn{2}{|l|}{ Total } & \multicolumn{2}{|c|}{ Chi-square $^{a}$} \\
\hline & $N$ & $\%$ & $N$ & $\%$ & $N$ & $\%$ & $N$ & $\%$ & $\chi^{2}$ & $p$-Value \\
\hline 3050-500 B.C. & $12 / 247$ & 4.9 & $14 / 278$ & 5.0 & $1 / 97$ & 1.0 & $27 / 622$ & 4.3 & 0.01 & 0.93 \\
\hline 500 B.C.-A.D. 420 & $18 / 545$ & 3.3 & $31 / 550$ & 5.6 & $1 / 213$ & 0.5 & $50 / 1308$ & 3.8 & 3.49 & 0.06 \\
\hline A.D. $420-1010$ & $20 / 665$ & 3.0 & $24 / 695$ & 3.5 & $7 / 298$ & 2.4 & $51 / 1654$ & 3.1 & 0.22 & 0.64 \\
\hline A.D. $1010-1390$ & $26 / 627$ & 4.1 & $34 / 597$ & 5.7 & $10 / 286$ & 3.5 & $70 / 1510$ & 4.6 & 1.57 & 0.21 \\
\hline A.D. $1390-1720$ & $15 / 349$ & 4.3 & $16 / 310$ & 5.2 & $0 / 130$ & 0 & $31 / 789$ & 4.1 & 6.69 & 0.04 \\
\hline A.D. $1720-1899$ & $12 / 147$ & 8.2 & $22 / 127$ & 17.3 & $1 / 45$ & 2.2 & $35 / 319$ & 11.0 & 5.26 & 0.02 \\
\hline Total & $103 / 2580$ & 4.0 & $141 / 2557$ & 5.5 & $20 / 1065$ & 1.9 & $264 / 6202$ & 4.3 & & \\
\hline$\chi^{2}$ & 9.64 & & 39.91 & & 9.66 & & 41.96 & & & \\
\hline$p$-Value & 0.09 & & $\leq 0.01$ & & 0.09 & & $\leq 0.01$ & & & \\
\hline
\end{tabular}

\footnotetext{
a Chi-square is between males and females for each time period.
} 
Table 8

Frequency of blunt force craniofacial trauma by ethnographic territory.

\begin{tabular}{|c|c|c|c|c|c|c|c|c|c|c|}
\hline \multirow[t]{2}{*}{ Ethnographic territory } & \multicolumn{2}{|l|}{ Female } & \multicolumn{2}{|l|}{ Male } & \multicolumn{2}{|c|}{ Indeterminate } & \multicolumn{2}{|l|}{ Total } & \multicolumn{2}{|c|}{ Chi-Square $^{\mathrm{a}}$} \\
\hline & $N$ & $\%$ & $N$ & $\%$ & $N$ & $\%$ & $N$ & $\%$ & $\chi^{2}$ & $p$-Value \\
\hline Bay Miwok & $9 / 202$ & 4.5 & $6 / 200$ & 3.0 & $3 / 85$ & 3.5 & $18 / 487$ & 3.7 & 0.59 & 0.44 \\
\hline Central Sierra Miwok & $0 / 4$ & 0 & $0 / 3$ & 0 & $0 / 4$ & 0 & $0 / 11$ & 0 & - & - \\
\hline Coast Miwok & $2 / 30$ & 6.7 & $3 / 40$ & 9.8 & $0 / 3$ & 0 & $5 / 73$ & 6.8 & - & - \\
\hline Costanoan & $48 / 1256$ & 3.8 & $69 / 1305$ & 5.3 & $8 / 603$ & 1.3 & $125 / 3164$ & 4.0 & 3.15 & 0.08 \\
\hline Hill Nomlaki & $3 / 84$ & 3.6 & $4 / 90$ & 4.4 & $0 / 19$ & 0 & $7 / 193$ & 3.6 & 0.09 & 0.77 \\
\hline River Nomlaki & $1 / 5$ & 20.0 & $3 / 7$ & 42.9 & $0 / 2$ & 0 & $4 / 14$ & 28.6 & - & - \\
\hline Northeastern Maidu & $0 / 3$ & 0 & $0 / 6$ & 0 & - & - & $0 / 9$ & 0 & - & - \\
\hline Northern Sierra Miwok & $0 / 115$ & 0 & $0 / 57$ & 0 & $0 / 53$ & 0 & $0 / 225$ & 0 & - & - \\
\hline Northern Valley Yokuts & $8 / 131$ & 6.1 & $7 / 126$ & 5.6 & 1 & 29 & $16 / 286$ & 5.6 & 0.04 & 0.6 \\
\hline Konkow & $2 / 54$ & 3.7 & $4 / 36$ & 11.1 & $0 / 43$ & 0 & $6 / 133$ & 4.5 & 1.91 & 0.17 \\
\hline Hill Patwin & $0 / 34$ & 0 & $0 / 30$ & 0 & $0 / 16$ & 0 & $0 / 80$ & 0 & - & - \\
\hline River Patwin & $1 / 27$ & 3.7 & $3 / 35$ & 8.6 & $1 / 10$ & 10 & $5 / 72$ & 6.9 & - & - \\
\hline Southern Patwin & $7 / 244$ & 2.9 & $9 / 267$ & 3.4 & $0 / 55$ & 0 & $16 / 566$ & 2.8 & 0.11 & 0.75 \\
\hline Plains Miwok & $10 / 234$ & 4.3 & $14 / 214$ & 6.5 & $5 / 90$ & 5.6 & $29 / 538$ & 5.4 & 1.14 & 0.29 \\
\hline Nisenan & $0 / 28$ & 0 & $0 / 18$ & 0 & $0 / 16$ & 0 & $0 / 62$ & 0 & - & - \\
\hline Southern Sierra Miwok & $1 / 74$ & 1.4 & $1 / 61$ & 1.6 & $0 / 17$ & 0 & $2 / 152$ & 1.3 & 0.02 & 0.89 \\
\hline Wintu & $8 / 28$ & 28.6 & $16 / 36$ & 44.4 & $2 / 7$ & 28.6 & $26 / 71$ & 36.3 & - & - \\
\hline Yana & $3 / 27$ & 11.1 & $2 / 25$ & 8.0 & $0 / 13$ & 0 & $5 / 65$ & 7.7 & - & - \\
\hline Wappo & $0 / 0$ & 0 & $0 / 1$ & 0 & $0 / 0$ & 0 & $0 / 1$ & 0 & - & - \\
\hline Total & $103 / 2580$ & 4.0 & $141 / 2557$ & 5.5 & $20 / 1065$ & 1.9 & $264 / 6202$ & 4.3 & & \\
\hline$\chi^{2}$ & 63.25 & & 140.86 & & 44.51 & & 234.71 & & & \\
\hline$p$-Value & $\leq 0.01$ & & $\leq 0.01$ & & $\leq 0.01$ & & $\leq 0.01$ & & & \\
\hline
\end{tabular}

${ }^{\text {a }}$ Chi-square is between males and females for each ethnographic territory.

Table 9

Frequency of blunt force craniofacial trauma by geographic region.

\begin{tabular}{|c|c|c|c|c|c|c|c|c|c|c|}
\hline \multirow[t]{2}{*}{ Geographic region } & \multicolumn{2}{|l|}{ Female } & \multicolumn{2}{|l|}{ Male } & \multicolumn{2}{|c|}{ Indeterminate } & \multicolumn{2}{|l|}{ Total } & \multicolumn{2}{|c|}{ Chi-square $^{\mathrm{a}}$} \\
\hline & $N$ & $\%$ & $N$ & $\%$ & $N$ & $\%$ & $N$ & $\%$ & $\chi^{2}$ & $p$-Value \\
\hline Sierra Nevada & $1 / 196$ & 0.5 & $1 / 127$ & 0.8 & $0 / 74$ & 0 & $2 / 397$ & 0.5 & 0.10 & 0.76 \\
\hline Central Valley & $52 / 1013$ & 5.1 & $62 / 1005$ & 6.8 & $12 / 331$ & 3.6 & $132 / 2349$ & 5.6 & 2.41 & 0.12 \\
\hline SF Bay & $50 / 1371$ & 3.6 & $72 / 1425$ & 5.1 & $8 / 660$ & 1.2 & $130 / 3456$ & 3.8 & 3.31 & 0.07 \\
\hline Total & $103 / 2580$ & 4.0 & $141 / 2557$ & 5.5 & $20 / 1065$ & 1.9 & $264 / 6202$ & 4.3 & & \\
\hline$\chi^{2}$ & 10.07 & & 9.05 & & 8.49 & & 26.50 & & & \\
\hline$p$-Value & 0.01 & & 0.01 & & 0.01 & & $\leq 0.01$ & & & \\
\hline
\end{tabular}

${ }^{\text {a }}$ Chi-square is between males and females for each geographic region.

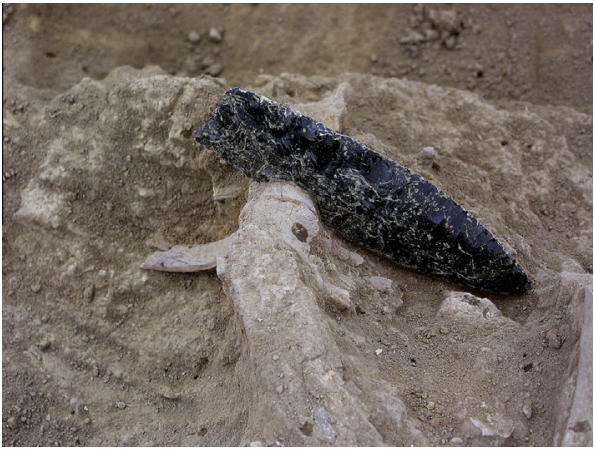

Fig. 7. Example of embedded projectile point, Burial 182, CA-CCO-548 (1500500 cal B.C.) (Photograph by Randy Wiberg).

With respect to temporal trends, overall frequencies of sharp force/projectile trauma show no significant variation across the first five of the six temporal periods represented in our sample, remaining steady between $6.2 \%$ and $7.5 \%$. However, a distinct increase from $7.4 \%(58 / 779)$ to $9.7 \%(31 / 319)$ is apparent during the Protohistoric/Historic Period (Table 11). Additional temporal variation is apparent when males are considered separately from females. While males mirror the overall study population with an all-time peak (15.6\%) in sharp force/projectile trauma during the Protohistoric/Historic Period, they exhibit an earlier peak during the Early Middle Period (11.9\%), followed by a decline in the Late Middle Period (9.2\%) and then a steady upward trend across the Middle-Late Transition through the Protohistoric/Historic Period. This trend contrasts markedly with patterning among females who show a concomitant decline in sharp force/projectile trauma during the Middle-Late Transition and Late Period, only increasing during the Protohistoric/Historic Period.

Sharp force/projectile trauma also shows variation by ethnographic territory (Table 12). Considering only those territories with robust samples ( $n>100$ ), the highest frequencies were among the southern Sierra Miwok (23.2\%), northern Valley Yokuts (9.7\%), and Hill Nomlaki (7.9\%). Statistically significant differences between males and females are seen in many regions including the Costanoan, Hill Nomlaki, Northern Valley Yokuts, Southern Patwin, and Plains Miwok. On a regional basis there is strong variation with the Sierra Nevada foothills exhibiting the highest frequencies of sharp force/projectile trauma ( $45 / 417$ or $10.8 \%$ ) with a gradual decline to the west; the Central Valley exhibits 9.6\% (203/2125) while the San Francisco Bay area has the lowest frequency at 5.7\% (214/ 3736) (Table 13). 
Table 10

Distribution of sharp force and projectile trauma by age.

\begin{tabular}{|c|c|c|c|c|c|c|c|c|c|c|}
\hline \multirow[t]{2}{*}{ Age } & \multicolumn{2}{|l|}{ Females } & \multicolumn{2}{|l|}{ Males } & \multicolumn{2}{|c|}{ Indeterminate } & \multicolumn{2}{|l|}{ Total } & \multicolumn{2}{|c|}{ Chi-Square $^{a}$} \\
\hline & $N$ & $\%$ & $N$ & $\%$ & $N$ & $\%$ & $N$ & $\%$ & $\chi^{2}$ & $p$-Value \\
\hline Adolescent (12-18) & $8 / 92$ & 8.7 & $4 / 53$ & 7.5 & $7 / 237$ & 3.0 & $19 / 382$ & 5.0 & 0.06 & 0.81 \\
\hline Young adult (18-35) & $58 / 1179$ & 4.9 & $144 / 1280$ & 11.3 & $10 / 355$ & 2.8 & $212 / 2814$ & 7.5 & 32.62 & $\leq 0.01$ \\
\hline Middle adult (35-45) & $26 / 590$ & 4.4 & $60 / 602$ & 10.0 & $1 / 81$ & 1.2 & $87 / 1273$ & 6.8 & 13.76 & $\leq 0.01$ \\
\hline Old adult (45+) & $16 / 513$ & 3.1 & $25 / 636$ & 6.9 & $0 / 66$ & 0 & $41 / 942$ & 4.4 & 6.77 & 0.01 \\
\hline Total & $108 / 2374$ & 4.5 & $233 / 2298$ & 10.0 & $18 / 739$ & 2.4 & $359 / 5411$ & 6.6 & & \\
\hline$\chi^{2}$ & 6.46 & & 6.36 & & 2.62 & & 13.38 & & & \\
\hline$p$-Value & 0.09 & & 0.95 & & 0.45 & & 0.01 & & & \\
\hline
\end{tabular}

a Chi-square is between males and females for each age group.

\section{Discussion}

\section{Spatial and cultural variability}

As recognized previously, central California seems to distinguish itself from the Santa Barbara Channel by a higher frequency of trophy-taking and dismemberment which, although mentioned ethnographically for the Chumash (Johnson, 2007; Lambert, 2007b), did not figure prominently in Lambert's (1994) assessment of the regional bioarchaeological record of violence. In central California evidence for trophy-taking/dismemberment seems to reflect a strategy of raiding, inter-group retribution, and mutilation for the purposes of intimidation. The overall occurrence of this form of violence is relatively low, however, with a frequency of only $0.7 \%$. This value is slightly higher when it is based only on skeletons for which sex determinations were made $(0.9 \%)$. The highest frequency in any area was 2.2\% (6/269) in the ethnographic territory of the River Patwin followed by $1.3 \%$ (63/4815) in Costanoan territory of the southern San Francisco Bay area. Two archaeological sites in the southern San Francisco Bay area did show noticeably higher frequencies of this form of violence: CASCL-478 produced six examples from a population of 90 (6.7\%) (Wiberg, 2002) while CA-SCL-674 produced 14 examples from a population of 243 (5.8\%) (Grady et al., 2001).

Compared to trophy taking, evidence for blunt force and sharp force/projectile trauma is considerably more abundant in central California with overall frequency of sharp force/projectile trauma at $7.4 \%(462 / 6278)$, and blunt force craniofacial trauma at $4.3 \%$ (264/6202). These two forms of violence were also identified in the Santa Barbara Channel where the overall frequency of sharp force trauma (3.3\%) was much lower than central California, but the prevalence of cranial vault fractures was much higher (15.1\%) (Lambert, 1994). Some of these reported differences in the frequency of violent behavior may be related to inconsistencies in researchers' definitions of skeletal indicators of violence. However, such distinctions might also reflect cultural variation in outlets for violence across Native California as others have noted (Andrushko et al., 2010). In central California spatial patterning in all forms of violence shows hot-zones in the southern San Francisco Bay area, and along the shores of the Sacramento River, particularly along the boundaries between the Bay Miwok, Plains Miwok, and River and Southern Patwin ethnographic groups (Fig. 4). The latter locations contained the highest ethnographic population densities which appear to have been a contributing factor to elevated levels of violence.

In central California the majority of blunt force craniofacial fractures were found on the parietal followed by the frontal. Walker postulated that the occurrence of antemortem depressed fractures on the frontal could be related to ritualized fighting, but his conclusion was also based on the extremely high frequency of this type of trauma in the Santa Barbara Channel. If this interpretation is correct, central California had lower rates of ritualized fighting than in the Santa Barbara Channel. Alternatively, this form of violence may have had a different cause across these different regions and did not serve a ritualized purpose in central California.

In the Santa Barbara Channel there was a decidedly lower frequency of both sharp force (males 9.6\%; females 3.7\% [Lambert, 1994:137]) and blunt force (males 23.8\%; females $13.5 \%$ [Lambert, 1994:114]) trauma among females, a pattern that is also manifest in central California in trophy-taking (males $1.4 \%$; females $0.4 \%$ ) and sharp force/projectile trauma (males 10.7\%; females $4.5 \%$ ). However, blunt force craniofacial trauma was nearly as common among females (4.0\%) as males (5.6\%). While found to have a statistical difference, the sexes were very similar in type, frequency, and location of blunt force craniofacial trauma. Where Andrushko et al. (2010) suggested that the occurrence of female skeletons subjected to trophy-taking or dismemberment were evidence of noncombatants being subjected to reciprocal, symbolic forms of

Table 11

Frequency of sharp force and projectile trauma by time period.

\begin{tabular}{|c|c|c|c|c|c|c|c|c|c|c|}
\hline \multirow[t]{2}{*}{ Time period } & \multicolumn{2}{|l|}{ Females } & \multicolumn{2}{|l|}{ Males } & \multicolumn{2}{|c|}{ Indeterminate } & \multicolumn{2}{|l|}{ Total } & \multicolumn{2}{|c|}{ Chi-square $^{a}$} \\
\hline & $N$ & $\%$ & $N$ & $\%$ & $N$ & $\%$ & $N$ & $\%$ & $\chi^{2}$ & $p$-Value \\
\hline 3050-500 В.С. & $5 / 247$ & 2.0 & $18 / 274$ & 6.6 & $16 / 113$ & 14.2 & $39 / 634$ & 6.2 & 6.36 & 0.01 \\
\hline 500 B.C.-A.D. 420 & $16 / 493$ & 3.2 & $65 / 548$ & 11.9 & $8 / 221$ & 3.6 & $89 / 1262$ & 7.1 & 26.85 & $\leq 0.01$ \\
\hline A.D. $420-1010$ & $44 / 728$ & 6.0 & $65 / 703$ & 9.2 & $20 / 308$ & 6.5 & $129 / 1739$ & 7.4 & 5.21 & 0.02 \\
\hline A.D. $1010-1390$ & $34 / 649$ & 5.2 & $65 / 593$ & 11.0 & $17 / 303$ & 5.6 & $116 / 1545$ & 7.5 & 13.83 & $\leq 0.01$ \\
\hline A.D. $1390-1720$ & $10 / 332$ & 3.0 & $40 / 307$ & 13.0 & $8 / 140$ & 5.7 & $58 / 779$ & 7.4 & 22.19 & $\leq 0.01$ \\
\hline A.D. $1720-1899$ & $9 / 145$ & 6.2 & $20 / 128$ & 15.6 & $2 / 46$ & 4.3 & $31 / 319$ & 9.7 & 6.35 & 0.01 \\
\hline Total & $118 / 2594$ & 4.5 & $273 / 2553$ & 10.7 & $71 / 1131$ & 6.3 & $462 / 6278$ & 7.4 & & \\
\hline$\chi^{2}$ & 12.74 & & 12.26 & & 15.20 & & 4.20 & & & \\
\hline$p$-Value & 0.03 & & 0.03 & & 0.01 & & 0.52 & & & \\
\hline
\end{tabular}

\footnotetext{
${ }^{a}$ Chi-square is between males and females for each time period.
} 
Table 12

Frequency of sharp force and projectile trauma by ethnographic territory.

\begin{tabular}{|c|c|c|c|c|c|c|c|c|c|c|}
\hline \multirow[t]{2}{*}{ Ethnographic territory } & \multicolumn{2}{|l|}{ Females } & \multicolumn{2}{|l|}{ Males } & \multicolumn{2}{|c|}{ Indeterminate } & \multicolumn{2}{|l|}{ Total } & \multicolumn{2}{|c|}{ Chi-square $^{a}$} \\
\hline & $N$ & $\%$ & $N$ & $\%$ & $N$ & $\%$ & $N$ & $\%$ & $\chi^{2}$ & $p$-Value \\
\hline Bay Miwok & $8 / 193$ & 4.1 & $16 / 209$ & 7.7 & $1 / 86$ & 1.2 & $25 / 488$ & 5.1 & 2.20 & 0.14 \\
\hline Central Sierra Miwok & $1 / 4$ & 25.0 & $0 / 3$ & 0 & $0 / 4$ & 0 & $1 / 11$ & 9.1 & - & - \\
\hline Coast Miwok & $1 / 30$ & 3.3 & $4 / 40$ & 10.0 & $0 / 3$ & 0 & $5 / 73$ & 6.8 & - & - \\
\hline Costanoan & $36 / 1269$ & 2.8 & $111 / 1260$ & 12.4 & $37 / 644$ & 5.7 & $184 / 3173$ & 5.8 & 41.20 & $\leq 0.01$ \\
\hline Hill Nomlaki & $4 / 83$ & 4.8 & $11 / 89$ & 12.4 & $0 / 19$ & 0 & $15 / 191$ & 7.9 & 3.07 & 0.08 \\
\hline River Nomlaki & $0 / 5$ & 0 & $0 / 3$ & 0 & $0 / 2$ & 0 & $0 / 10$ & 0 & - & - \\
\hline Northeastern Maidu & $0 / 3$ & 0 & $2 / 6$ & 33.3 & - & - & $2 / 9$ & 22.2 & - & - \\
\hline Northern Sierra Miwok & $2 / 116$ & 1.7 & $2 / 64$ & 33.3 & $0 / 53$ & 0 & $4 / 233$ & 1.7 & 0.37 & 0.54 \\
\hline Northern Valley Yokuts & $8 / 128$ & 6.3 & $20 / 134$ & 14.9 & $0 / 28$ & 0 & $28 / 290$ & 9.7 & 5.16 & 0.02 \\
\hline Konkow & $0 / 54$ & 0 & $1 / 40$ & 2.5 & $6 / 49$ & 12.2 & $7 / 143$ & 4.9 & 1.37 & 0.24 \\
\hline Hill Patwin & $1 / 35$ & 2.9 & $5 / 35$ & 14.3 & $1 / 17$ & 5.9 & $7 / 87$ & 8.0 & - & - \\
\hline River Patwin & $6 / 35$ & 17.1 & $19 / 37$ & 51.4 & $0 / 9$ & 0 & $25 / 81$ & 30.9 & - & - \\
\hline Southern Patwin & $4 / 241$ & 1.7 & $13 / 257$ & 5.1 & $1 / 56$ & 1.8 & $18 / 554$ & 3.2 & 4.36 & 0.04 \\
\hline Plains Miwok & $22 / 235$ & 9.4 & $40 / 230$ & 17.4 & $16 / 101$ & 15.8 & $78 / 566$ & 3.2 & 6.49 & 0.01 \\
\hline Nisenan & $3 / 28$ & 10.7 & $6 / 19$ & 31.6 & $6 / 22$ & 27.3 & $15 / 69$ & 21.7 & - & - \\
\hline Southern Sierra Miwok & $20 / 80$ & 25.0 & $16 / 65$ & 24.6 & $2 / 19$ & 10.5 & $38 / 164$ & 23.2 & 0.00 & 0.96 \\
\hline Wintu & $1 / 27$ & 3.7 & $5 / 36$ & 13.9 & $1 / 6$ & 16.7 & $7 / 69$ & 10.1 & - & - \\
\hline Yana & $1 / 27$ & 3.7 & $2 / 25$ & 8.0 & $0 / 13$ & 0 & $3 / 65$ & 4.6 & - & - \\
\hline Wappo & $0 / 1$ & 0 & $0 / 1$ & 0 & - & - & $0 / 2$ & 0 & - & - \\
\hline Total & $118 / 2594$ & 4.5 & $273 / 2553$ & 10.7 & $71 / 1131$ & 6.3 & $462 / 6278$ & 7.4 & & \\
\hline$\chi^{2}$ & 128.38 & & 126.52 & & 51.67 & & 229.56 & & & \\
\hline$p$-Value & $\leq 0.01$ & & $\leq 0.01$ & & $\leq 0.01$ & & $\leq 0.01$ & & & \\
\hline
\end{tabular}

a Chi-square is between males and females for each ethnographic territory.

Table 13

Frequency of sharp force and projectile trauma divided by geographic region.

\begin{tabular}{|c|c|c|c|c|c|c|c|c|c|c|}
\hline \multirow[t]{2}{*}{ Geographic region } & \multicolumn{2}{|l|}{ Females } & \multicolumn{2}{|l|}{ Males } & \multicolumn{2}{|c|}{ Indeterminate } & \multicolumn{2}{|l|}{ Total } & \multicolumn{2}{|c|}{ Chi-square $^{\mathrm{a}}$} \\
\hline & $N$ & $\%$ & $N$ & $\%$ & $N$ & $\%$ & $N$ & $\%$ & $\chi^{2}$ & $p$-Value \\
\hline Sierra Nevada & $23 / 203$ & 11.3 & $20 / 138$ & 14.5 & $2 / 76$ & 2.6 & $45 / 417$ & 10.8 & 0.75 & 0.39 \\
\hline Central Valley & $50 / 898$ & 5.6 & $122 / 905$ & 13.5 & $31 / 322$ & 9.6 & $203 / 2125$ & 9.6 & 32.70 & $\leq 0.01$ \\
\hline SF Bay & $45 / 1493$ & 3.0 & $131 / 1510$ & 8.7 & $38 / 733$ & 5.2 & $214 / 3736$ & 5.7 & 43.62 & $\leq 0.01$ \\
\hline Total & $118 / 2594$ & 4.5 & $273 / 2553$ & 10.7 & $71 / 1131$ & 6.3 & $462 / 6278$ & 7.4 & & \\
\hline$\chi^{2}$ & 31.75 & & 15.89 & & 9.35 & & 36.79 & & & \\
\hline$p$-Value & $\leq 0.01$ & & $\leq 0.01$ & & 0.01 & & $\leq 0.01$ & & & \\
\hline
\end{tabular}

a Chi-square is between males and females for each geographic region.

violence, the similarity in male and female percentages of blunt force trauma suggest that females in central California may have been at least slightly more active in aggressive interactions between groups, a finding supported by regional ethnographic accounts; however, central California ethnography and bioarchaeology in general support previously identified patterns of greater participation of males in acts of violence. The slightly higher frequency of evidence for violent trauma in females in central California in comparison to the Santa Barbara Channel could also be attributed to female aggression directed at other females. In a cross-cultural study, it was found that this type of behavior can be the result of competition for men or scarce resources (Burbank, 1987). In modern Zambia female aggression was also found to equate to social status and its role in resource acquisition (Schuster, 2006). This higher rate of female craniofacial trauma could also be a result of domestic fighting, and the result of male aggression directed at females.

\section{Diachronic variability}

Variation through time in central California is seemingly more informative than inter-regional comparisons and simple spatial patterning in terms of the possible causes of violence, or at the very least, correlative variables. At present, diachronic variation can only be evaluated on a coarse-grained chronological scale in which burials were assigned to relatively large blocks of time. This same chronological approach was employed in the Santa Barbara area where Walker (1989) and Lambert (1994) found that evidence of intra-group/intra-personal violence did not simply increase incrementally over time but rather there were two intervals of heightened violence: the Early Middle Period (1500 cal B.C-A.D. 580) when blunt force cranial trauma showed exceptionally high frequencies (36.5\% in males, $19.4 \%$ in females) and the Late Middle Period (cal A.D. 580-1380) when projectile point injuries peaked (21.9\% males, 10.7\% females) (Fig. 8). Walker (1989) attributed the earlier spike to sub-lethal combat focused on the Channel Islands (although Lambert (1994:109) found equal or greater rates of cranial trauma on the mainland) while the Late Middle increase in sharp force trauma was associated with both the introduction of the bow and arrow, and resource scarcity during droughts of the Medieval Climatic Anomaly (Lambert, 1994).

Central California also shows episodic violence rather than a gradual, incremental increase that might be expected from simple population growth over time. Here also, two periods are apparent, but they differ from those identified in southern California. Trophy-taking/dismemberment shows an apex during the Early Middle Period (500 B.C.-A.D. 420), followed by a significant decline with virtually no evidence of this form of violence during the Protohistoric/Historic Period (A.D. 1720-1899) (Fig. 8). The timing of this peak is very similar to the early apex in blunt force cranial trauma in southern California. The second apex in violence in central California was during the Protohistoric/Historic Period (cal A.D. 
1720-1899) which shows all-time high frequencies of both blunt force and sharp force/projectile trauma. This differs significantly from the Santa Barbara Channel where the peak in projectile violence was earlier (cal A.D. 580-1380) and was followed by a marked decline. Clearly, the Early Middle Period, while dated slightly differently across regions stands out as a period of escalated violence in both central and southern California, with high levels of blunt force trauma in the south, and elevated levels of trophy-taking and projectile violence in the central part of the state. The peak in Early Middle Period violence in central California, however, is also very different and much more severe than that seen in the Santa Barbara Channel area. In the latter area the depressed cranial injuries are rather small and healed, and there is minimal evidence for lethal intention (Lambert, 1994, 1997). The trophytaking, on the other hand suggests a very different level and type of violence, one that may well have had a symbolic component to it that was related to intimidation, power, and acts of retaliation.

While the emphasis on trophy-taking seems to be the salient characteristic of violence during the Early Middle Period in central California, this interval also shows an increase in sharp force/projectile trauma from the Early Period. Stevens and Codding (2009) have suggested that the atlatl spear-thrower may not have been introduced into California until the Middle Period. While more evidence will be needed to overturn the prevailing view that the atlatl has a much greater antiquity in California, our projectile violence data do provide some support for a shorter chronology at least in the central part of the state. More compelling is the increase in sharp force/projectile trauma during the Middle-Late Transition, which seems to reflect the appearance of the bow and arrow. This weapon system was apparently introduced into eastern California (Sutton et al., 2007:241) and the American Southwest (Cordell, 1984:102) as early as A.D. 400-600, but Lambert (1994) was unable to document evidence for its use in the Santa Barbara Channel any earlier than ca. cal A.D. 980. A more recent review of the dating evidence by Kennett et al. (2013) now suggests its appearance in the Channel Islands area between cal A.D. 650 and 900, but a later date, ca. cal A.D. 1200, for its introduction into central California (see also Groza et al., 2011:151). Kennett et al. (2013) suggest that the initial appearance of the bow in the Santa Barbara area did not immediately precipitate increased violence but that bow-related violence only became more prevalent in the context of later climatic instability during the Medieval Climatic Anomaly. Our data from central California show a strong correlation between the currently accepted date for the arrival of the bow and arrow (cal A.D. 1200) and increased violence. The relatively high frequency of sharp force trauma in the Sierra Nevada and a decrease from east to west from the Sierra to San Francisco Bay (Table 12) further corroborate the notion that the bow was introduced into central California from the east (Bettinger, 2013; Kennett et al., 2013). The fact that this pattern is stronger during the Late Period (Table 14), further supports this likelihood.

The correlation between increased violence and the bow suggested in our data is also not concordant with Bettinger's (2013) recent assessment of the relative importance of this weapon system in central California over time. He argued that California-Great Basin warfare seemed never to have been organized enough to put

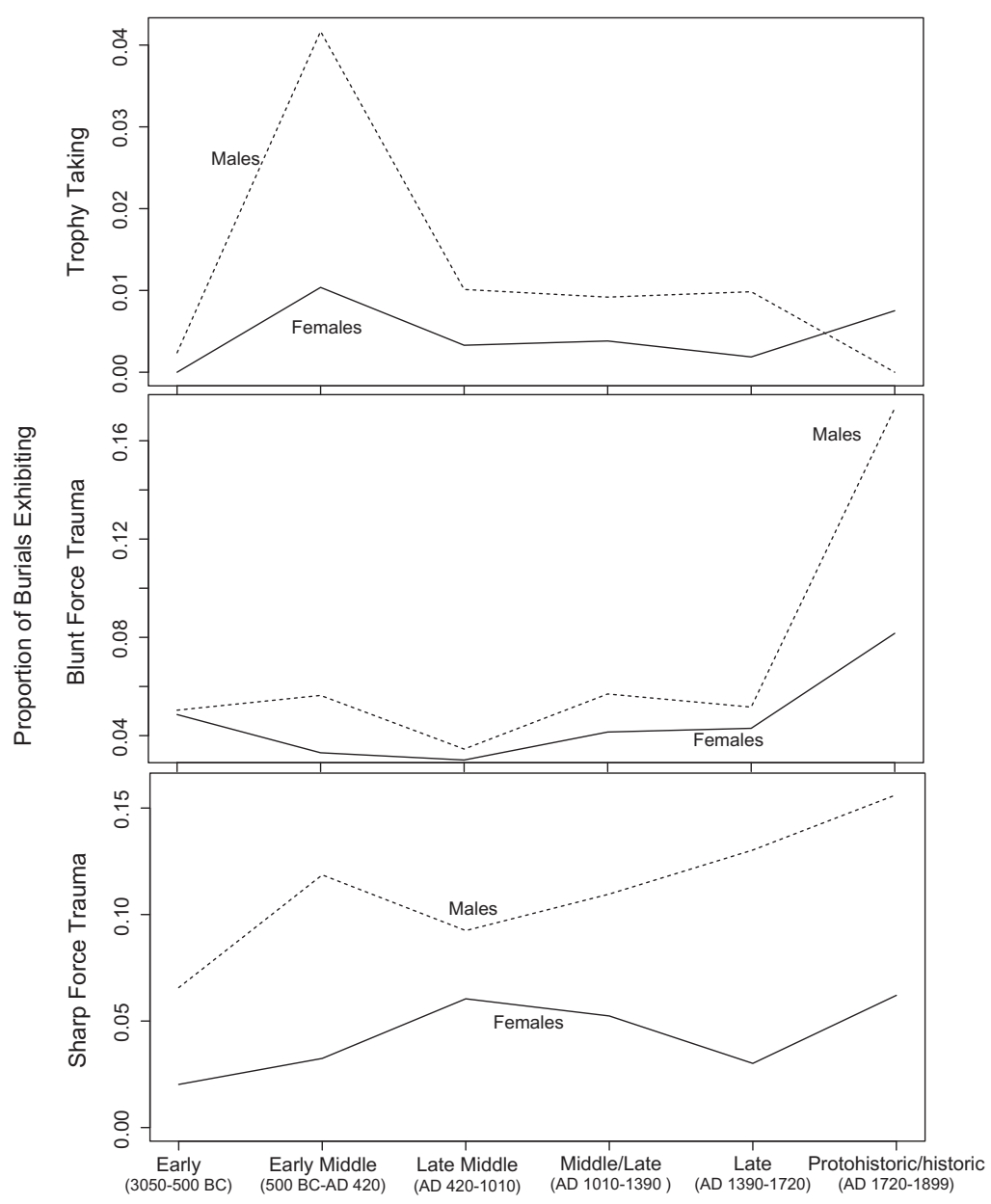

Fig. 8. Relative frequency of trophy-taking/dismemberment, blunt force trauma, and sharp force trauma through time for males and females in central California. 
the bow to effective use and that bow-related violence played itself out in the Santa Barbara Channel by A.D. 1150. In contrast, our central California data show only a continuously upward trend following the introduction of the bow. Much of Bettinger's assessment of the nature of central California warfare may still be accurate (the lack of shields, armor, and implements of war among most groups), but the diachronic trend in bow-related violence suggests that the appearance of the new weapon system brought with it an increase in inter-group and/or inter-personal attacks.

We concur with Andrushko et al. (2010), however, that pre-bow and arrow violence in central California during the Early Middle Period was most likely related to the intrusion of different groups into and through the Sacramento Delta and southern San Francisco Bay area.

Circa 1500 cal B.C., central California was marked by the cooccurrence of at least three distinctive artifact complexes: Windmiller (Sacramento Valley/Delta), Berkeley (East San Francisco Bay), and Early Bay (southwest San Francisco Bay), which have long been thought to reflect different ethnolinguistic identities, specifically subdivisions of the Penutian language family and possibly the Hokan stock (Fredrickson, 1974; Gerow and Force, 1968; Moratto, 1984). Of course, the exact correlation between these archaeological cultures, languages, and ethnic identities is imprecise, complex, and much debated (see Hughes, 1992). More recent research has sought to unravel the history of population group movements in central California via ancient DNA (e.g., Johnson et al., 2012) producing yet more complex patterning. Still, the linguistic mosaic of central California cannot be credibly explained without reference to past population migrations (Codding and Jones, 2013). By the beginning of the Late Period (ca. cal A.D. 1250) the Augustine Pattern became dominant throughout both the Sacramento Delta and San Francisco Bay regions shared by several ethnolinguistic groups (Bay Miwok, Costanoan, Plains Miwok, Patwin). The concentration of signs of violence along the boundaries between groups suggests that the process of them all establishing themselves in central California was not entirely peaceful. The concentration of sites with evidence of violence in the southern San Francisco Bay area suggests that this was a hot-zone of inter-group contact and conflict during much of the prehistoric past, initially as an interface between the Early Bay and Berkeley archaeological complexes during the Early Middle Period, and later during the Middle Period between the established (Berkeley), and its replacement, the Augustine culture. The earlier inter-group conflict featured trophy-taking/dismemberment and projectile trauma, both with a heavy emphasis on male victims.

Diachronic patterns provide only ambiguous support for the Medieval droughts hypothesis in central California. In the Santa Barbara Channel, effects of the droughts are well attested by the extreme peak in projectile violence during the Middle-Late Transition when the droughts occurred, and a decrease with climatic amelioration in the ensuing Late Period. In central California our database shows an increase in projectile violence coincident with the MCA when the bow and arrow seems to have been introduced, making it difficult to discern which factor-drought-related stress or introduction of a new weapon-was most important in effecting increased violence. This situation is similar to eastern North America where bow-related violence increased during the late Woodland Period when there was also widespread settlement and subsistence change- making it impossible (and probably not realistic) to determine which variable was more significant in causing societal change (Milner et al., 2013). However, in central California violence continued to increase to even greater levels after the introduction of the bow during the Middle-Late Transition, reaching an all-time peak during Protohistoric/Historic times, suggesting the new weapon system may ultimately have been a more powerful influence than the Medieval droughts. Schwitalla and Jones (2012), using an earlier version of the CCDB, also found only modest evidence for increased violence in central California during the Middle-Late Transition as a whole. Specifically, they found no signs of elevated levels of violence in the Sacramento Delta or the Sacramento Valley, but did document a modest increase during the late Medieval period (ca. cal A.D. 1200-1390) in the San Francisco Bay area by using a more fine-grained chronology than we employ in the current paper.

The degree to which diachronic patterns of violence in central California correlate with socio-political complexity is equivocal largely due to a lack of a regional consensus on the level of complexity in the San Francisco Bay and Central Valley regions, and the broader archaeological evidence for complexity in these regions. The suggestion by Andrushko et al. (2010) that the increase in trophy-taking/dismemberment during the Early Middle Period suggests emergent political complexity could be valid, but this leaves unexplained the decline that followed. We can perhaps assume that the ecological and cultural context that precipitated this particular form of symbolic violence changed by the end of the Middle Period since humans certainly have the ability to develop different solutions and reveal different outcomes in the context of varied external and internal circumstances. Trophy taking may have been initiated in response to or in concert with emergent political complexity, but then disappeared, possibly after newlyarrived incoming migrants settled in and became well-established.

Overall, the Protohistoric/Historic Period (A.D. 1720-1899) showed the highest levels of blunt force and sharp force/projectile trauma in the central California sample. Almost certainly this late surge in violence can be attributed to the presence of Europeans who had established themselves in Mexico and the American Southwest 200-300 years earlier. Problems experienced by people who were in direct conflict with Europeans probably had a rippling effect throughout indigenous western North America as people tried to migrate away from the zones of direct contact and conflict. Certainly these movements and their effects are fairly well documented in eastern North America (e.g., Worth, 1995). This same

Table 14

Frequency of sharp force and projectile trauma by time period and geographic region.

\begin{tabular}{|c|c|c|c|c|c|c|c|c|}
\hline \multirow[t]{3}{*}{ Geographic region } & \multicolumn{4}{|l|}{ Male } & \multicolumn{4}{|l|}{ Female } \\
\hline & \multicolumn{2}{|l|}{ Early } & \multicolumn{2}{|l|}{ Late } & \multicolumn{2}{|l|}{ Early } & \multicolumn{2}{|l|}{ Late } \\
\hline & $\mathrm{N}$ & $\%$ & $\mathrm{~N}$ & $\%$ & $\mathrm{~N}$ & $\%$ & $\mathrm{~N}$ & $\%$ \\
\hline Sierra Nevada & $11 / 101$ & 10.9 & $9 / 37$ & 24.3 & $16 / 136$ & 11.8 & $11 / 101$ & 10.9 \\
\hline Central Valley & $72 / 606$ & 11.9 & $50 / 299$ & 16.7 & $26 / 575$ & 4.5 & $72 / 606$ & 11.9 \\
\hline SF Bay & $65 / 818$ & 7.9 & $66 / 692$ & 9.5 & $23 / 757$ & 3.0 & $65 / 818$ & 7.9 \\
\hline Total & $148 / 1525$ & 9.7 & $125 / 1028$ & 12.2 & $65 / 1468$ & 4.4 & $148 / 1525$ & 9.7 \\
\hline$\chi^{2}$ & 6.32 & & 15.41 & & 20.76 & & 6.33 & \\
\hline$p$-Value & 0.04 & & $\leq 0.01$ & & $\leq 0.01$ & & 0.04 & \\
\hline
\end{tabular}


process has been argued to explain the spread of diseases throughout the New World in advance of the Europeans themselves (e.g., Erlandson and Bartoy, 1995; Preston, 2004)). Such a rippling effect may also help explain the concomitant increase in trophy-taking and blunt force cranial trauma during the Early Middle Period in both central California and the Santa Barbara Channel as the intrusion and spread of new groups into the center of the state may have had noticeable effects even upon those who were not in direct contact with the immigrants.

One final change through time involves discrepancies between the archaeological, historical, and salvage ethnographic records in regard to the role of children in inter-group conflict. Salvage ethnographic accounts from the early 20th century include descriptions of children being kidnapped and/or killed by enemy combatants, but earlier contact-era eyewitness accounts rarely featured children as targets or victims of violent tribal encounters. Likewise, the bioarchaeological record shows few incidents of children subjected to dismemberment, projectile violence or blunt force trauma. Although children could still have been subject to nonlethal violence, the available skeletal record suggests that it was not until the colonizers of California started conducting punitive raids that death among children in battlefield skirmishes and village massacres became widespread.

\section{Summary and conclusions}

The most abundant forms of violence in central California were sharp force/projectile trauma, blunt force craniofacial trauma, and trophy-taking/dismemberment. Evidence of violence is concentrated in two areas: (1) those with the highest ethnographic population densities (Sacramento River), and (2) the southern San Francisco Bay area. The higher level of violence in the former area could well reflect competition for resources related to high, densely-packed populations while the latter area seems to have been a location where conflicts between established residents and incoming migrant groups occurred relatively frequently.

Violence in general was more common among males; although, there is less sex-difference in blunt force craniofacial trauma in central California than in southern California. These results may suggest greater participation by females in this form of violence, which is also described in regional ethnographic and historic eyewitness accounts. Alternatively, these higher rates of violence among women may suggest they were more frequently the recipients of violent behavior than in other regions of California, which could be related to domestic violence or even within group struggles between females.

Temporal patterning shows two episodes of elevated violence: the Early Middle Period (500 cal B.C.-cal A.D. 420) marked primarily by a spike in trophy-taking/dismemberment along with increased sharp force trauma, and the Protohistoric/Historic Period (cal A.D. 1720-1899) marked by high levels of blunt force and sharp force trauma. The early peak which seems related to the arrival of new ethnolinguistic groups into central California is also synchronous with an apex in healed cranial fractures in the Santa Barbara Channel. The Early Middle Period was clearly a time of widespread violence in California albeit of regionally varied character. The second peak in violence was preceded by an initial increase in sharp force/projectile trauma during the Middle-Late Transition which coincided with the appearance of the bow and arrow ca. cal A.D. 1000-1200. While this increase may reflect resource scarcity during droughts of the Medieval Climatic Anomaly, sharp force/projectile trauma did not decline in central California at the conclusion of the Medieval droughts as it did in the Santa Barbara area. Instead, sharp force/projectile violence continued to increase, reaching a zenith at a time when Europeans had established themselves in southwestern North America. Their presence seems to have had a rippling effect on societies with whom they were not yet in direct contact.

Perhaps not surprisingly, our study has not allowed us to identify a single over-arching factor that explains patterned violence in prehistoric California. Resource stress related in some cases to environmental flux and in others to high population densities seems to have in some cases influenced the frequency and character of violence. Cultural events in the form of the appearance and movement of new groups and the diffusion of new technologies (weapons in particular) were likewise influential.

\section{Acknowledgments}

The authors dedicate this article to the memory of central California archaeologist Kenneth R. Bethard (Randy) with respect and gratitude. In both the lab and field Randy's presence, sense of humor, and professional contributions are missed. The authors thank the following individuals for providing primary data to the CCBD and helpful insights during production and review: Mark W. Allen, Robert L. Bettinger, Jennifer Blake, Colin Busby, Gary S. Breschini, Christopher Canzonieri, Kimberly Carpenter, Robert Cartier, Matthew R. Clark, Lisa Deitz, Stephen A. Dietz, Diane DiGiuseppe, Stella D’Oro, Jelmer Eerkens, Sally R. Evans, Gerrit L. Fenenga, Richard T. Fitzgerald, Michael R. Fong, Mark C. Griffin, Charlane Gross, Lori D. Hager, Jeff T. Hall, Lori Harrington, William R. Hildebrandt, Sandra E. Hollimon, Jerald J. Johnson, Robert D. Jurmain, Roger M. La Jeunesse, Sarah W. Kansa, Douglas J. Kennett, Susan Kerr, Patricia M. Lambert, Christine E. Marshall, Henry M. McHenry, George R. Milner, Penny Minturn, James S. Nelson, William H. Olsen, Allen G. Pastron, Ann Peak, Melinda Peak, Lisa Pesnichak, John H. Pryor, Alisa L. Reynolds, Francis A. Riddell, Eric W. Ritter, Christopher B. Ruff, Peter D. Schulz, Lisa A. Shapiro, Randy R. Skelton, Eric C. Strother, Melody Tannam, Katie A. Vallaire, Phillip L. Walker, Greg White, and Tim D. White.

\section{Appendix A. Supplementary material}

Supplementary data associated with this article can be found, in the online version, at http://dx.doi.org/10.1016/j.jaa.2013.11.004.

\section{References}

Aginsky, B.W., 1943. Cultural element distribution XXIV, central Sierra. Univ. Calif. Publ. Am. Archaeol. Ethnol., 8.

Allen, M.W., 2012. A land of violence. In: Jones, T.L., Perry. J A. (Eds.), Contemporary Issues in California Archaeology. Left Coast Press, Walnut Creek, California, pp. 93-114.

Andrushko, V.A., Latham, K.A., Grady, D.L., Pastron, A.G., Walker, P.L., 2005. Bioarchaeological evidence for trophy-taking in prehistoric central California. Am. J. Phys. Anthropol.

Andrushko, V.A., Schwitalla, A.W., Walker, P.L., 2010. Trophy-taking and dismemberment as warfare strategies in prehistoric central California. Am. J. Phys. Anthropol. 141, 83-96.

Arnold, J.E., 1992. Complex hunter-gatherer-fishers of prehistoric California: chiefs, specialists, and maritime adaptations of the Channel Islands. Am. Antiq. 57, 6084.

Arnold, J.E., 1997. Bigger boats, crowded creekbanks: environmental stresses in perspective. Am. Antiq. 62, 337-339.

Arnold, J.E., 2001. The Origins of a Pacific Coast Chiefdom: The Chumash of the Channel Islands. University of Utah Press, Salt Lake City.

Barrett, S.A., Gifford, E.W., 1933. Miwok Material Culture: Indian Life of the Yosemite Region. Cannon Printing Company, Milwaukee.

Bartelink, E.J., 2009. Late Holocene dietary changes in San Francisco Bay: stable isotope evidence for an expansion in diet breadth. Calif. Archaeol. 1, 227-252.

Bartelink, E.J., Andrushko, V.A., Bellifemine, V., Nechayev, I., Jurmain, R., 2013. Violence and warfare in the preshitoric San Francisco Bay Area, California: regional and temporal variations in conflict. In: Knusel, C., Smith, M. (Eds.), The Routledge Hbook of the Bioarchaeology of Human Conflict. Taylor and Francis, Oxford, pp. 285-307.

Basgall, M.E., 1987. Resource intensification among hunter-gatherers: acorn economies in prehistoric California. Res. Econ. Anthropol. 9, 21-52.

Basgall, M.E., 1999. Comment. Curr. Anthropol. 9, 21-52 
Baumhoff, M.A., 1963. Ecological determinants of aboriginal California populations. Univ. Calif. Publ. Am. Archaeol. Ethnol. 49, 155-336.

Beals, R.L., 1933. Ethnology of the Nisenan. Univ. Calif. Publ. Am. Archaeol. Ethnol. 31, 335-414.

Bettinger, R.L., 1999. Comment on environmental imperatives reconsidered: demographic crises in western North America during the medieval climatic anomaly. Curr. Anthropol. 40, 158-159.

Bettinger, R.L., 2013. Effects of the bow on social organization in western North America. Evol. Anthropol. 22, 118-123.

Bledsoe, A.J., 1885. Indian Wars of the Northwest: A California Sketch. Bacon and Company, San Francisco.

Bolton, H.E.T., 1926. Historical Memoirs of New California, vol. IV. University of California Press, Berkeley, California.

Bolton, H.E.T., 1930. Anza's California Expeditions Volume IV Font's Complete Diary of the Second Anza Expedition. University of California Press, Berkeley, California.

Bryant, E., 1967. What I Saw in California: Being the Journal of a Tour by the Emigrant Route and South Pass of the Rocky Mountains, Across the Continent of North America, the Great Desert Basin, and Through California, in the Years 1846, 1847. Ross and Haines, Minneapolis, Minnesota.

Bunnell, L.H., 1911. Letter to Father from Hart's Ranch, California, January 16, 1851. In Discovery of the Yosemite and the Indian War of 1851 which led to that Event. G.W. Gerlicher, Los Angeles.

Burbank, V., 1987. Female aggression in cross-cultural perspective. Cross-Cultural Res. 21, 70-100.

Camp, C.L., 1966. George C. Yount and his Chronicles of the West Comprising Extracts from his memoirs and from the Orange Clark Narrative. Old West Publishing Company, Denver, Colorado.

Chacon, R.J., Dye, D.H. 2007. Introduction to human trophy taking: an ancient and widespread practice. In: Chacon, R.J., Dye, D.H. (Eds.), The Taking and Displaying of Human Body Parts as Trophies by Amerindians. Springer, New York, pp. 5-31.

Codding, B.F., Jones, T.L., 2013. Environmental productivity predicts colonization, migration, and demographic patterns in prehistoric California. Proc. Natl. Acad. Sci. 110, 14569-14573.

Cook, S.F., 1967. Conflict between the California Indian and white civilization. In: Heizer, R.F., Whipple, M.A. (Eds.), The California Indians: A Source Book. University of California Press, Berkeley, California.

Cook, S.F., 1976. The Population of the California Indians, 1769-1970. University of California Press, Berkeley, California.

Cordell, L.S., 1984. Prehistory of the Southwest. Academic Press, Orlando.

D’Oro, S., 2009. Native Californian Prehistory and Climate in the San Francisco Bay Area Anthropology. San Jose State University, San Jose.

Driver, H.E., 1936. Wappo ethnography. Univ. Calif. Publ. Am. Archaeol. Ethnol. 36, 179-219.

DuBois, C., 1935. Wintu ethnography. Univ. Calif. Publ. Am. Archaeol. Ethnol. 36, 1148.

Ember, C.R., Ember, M., 1992. Resource unpredictability, mistrust and war: a crosscultural study. J. Conflict Resolut. 36, 242-262.

Erlandson, J.M., Bartoy, K., 1995. Cabrillo, the Chumash, and old world diseases. J. Calif. Great Basin Anthropol. 17, 153-173.

Erlandson, J.M., Rick, T.C., 2002. Late Holocene cultural developments along the Santa Barbara coast. In: Erlandson, J.M., Jones, T.L. (Eds.), Catalysts to Complexity: Late Holocene Societies of the California Coast. University of California, Los Angeles, Cotsen Institute of Archaeology, pp. 166-182.

Fischman, J., 1996. California social climbers: low water prompts high status. Science 272, 811-812.

Fredrickson, D.A., 1974. Cultural diversity in early central California: a view from the North Coast Ranges. J. Calif. Anthropol. 1, 41-54.

Fry, D.P., 2006. The Human Potential for Peace: An Anthropological Challenge to Assumptions about War and Violence. Oxford University Press, New York.

Galloway, A., 1999. Broken Bones: Anthropological Analysis of Blunt Force Cranial Trauma. Charles C. Thomas, Springfield, Illinois.

Gamble, L., 2005. Culture and climate: reconsidering the effect of palaeoclimatic variability among southern California hunter-gatherer societies. World Archaeol. 37, 92-108.

Gamble, L.H., 2008. The Chumash World at European Contact: Power, Trade, and Feasting among Complex Hunter-Gatherers. University of California Press, Berkeley, California.

Gayton, A.H., 1948. Yokuts and western Mono ethnography II: northern foothill Yokuts and western Mono. Univ. Calif. Anthropol. Rec. 10, 1-302.

Gerow, B.A., Force, R., 1968. An Analysis of the University Village Complex with a Reappraisal of Central California Archaeology. Stanford University Press, Stanford, California.

Gifford, E.W., 1940. Californian bone artifacts. Univ. Calif. Anthropol. Rec. 3, 153237.

Gifford, E.W., Klimek, S., 1937. Cultural element distribution: II, Yana. Univ. Calif. Publ. Am. Archaeol. Ethnol. 37, 71-100.

Gifford, E.W., Kroeber, A.L., 1937. Cultural element distribution: IV, Pomo. Univ. Calif. Publ. Am. Archaeol. Ethnol. 37, 117-254.

Glassow, M.A., Gamble, L.H., Perry, J.E., Russell, G.S., 2007. Prehistory of the northern California bight and the adjacent Transverse Ranges. In: Jones, T.L., Klar, K.A. (Eds.), California Prehistory: Colonization, Culture, and Complexity. AltaMira Press, Lanham, MD, pp. 191-214.

Goerke, B., 2007. Chief Marin: Leader, Rebel, and Legend. Heyday Press, Berkeley, California.
Goldschmidt, W., 1976. Social organization and status differentiation among the Nomlaki. In: Bean, L.J., Blackburn, T.C. (Eds.), Native Californians: A Theoretical Retrospective. Ballena Press, Menlo Park, California.

Goldschmidt, W., Foster, G., Essene, F., 1939. War stories from two enemy tribes. J. Am. Folk. 52, 141-154.

Golla, V., 2011. California Indian languages. University of California Press, Berkeley, California.

Grady, D.L., Latham, K.A., Andrushko, V.A., 2001. Archaeological Investigations at CA-SCL-674, the Rubino Site, City of San Jose, Santa Clara County, California, vol. II. Human Skeletal Biology of CA-SCL-674, Archives of California Prehistory 50 Salinas, California.

Gray, T.B., 1993. The Stanislaus Indian Wars: The Last of the California Northern Yokuts. McHenry Museum Press, Modesto, California.

Groza, R., 2002. An AMS Chronology for Central California Olivella Shell Beads California State University, San Francisco, San Francisco.

Groza, R., Rosenthal, J., Southon, J., Milliken, R., 2011. A refined shell bead chronology for central California. J. Calif. Great Basin Anthropol., 31.

Guilane, J., Zammit, J., 2001. Origins of War: Violence in Prehistory. Blackwell, Malden, MA.

Heizer, R.F., 1949. The Archaeology of Central California I: The Early Horizon. Anthropological Records, vol. 12:1. University of California Press, Berkeley California.

Hughes, R.E., 1992. California archaeology and linguistic prehistory. J. Anthropol Res. 48, 317-338.

Hughes, R.E., Milliken, R.T., 2007. Prehistoric matrial conveyance. In: Jones, T.L., Klar K.A. (Eds.), California Prehistory: Colonization, Culture, and Complexity. AltaMira Press, Lanham, MD.

Hurlbut, S.A., 2000. The taphonomy of cannibalism: a review of anthropogenic bone modification in the American Southwest. Int. J. Osteoarchaeol. 10, 426.

Hylkema, M., 2002. Tidal marsh, oak woodlands, and cultural florescence in the southern San Francisco Bay region. In: Erlandson, J.M., Jones, T.L. (Eds.), Catalysts to Complexity: Late Holocene Societies of the California Coast Cotsen Institute of Archaeology. University of California, Los Angeles.

James, S.R., Graziani, S., 1975. California Indian warfare. Contributions of the University of California Archaeological Research Facility 23, 47-109.

Jazwa, C., Kennett, D.J., Hanson, D., 2012. Late Holocene subsistence change and marine productivity on western Santa Rosa Island, Alta California. Calif Archaeol. 4, 69-98.

Jewell, D.P. 1987. Indians of the Feather River: Tales and Legends of Concow Maidu of California. Ballena Press, Menlo Park, California.

Johnson, J.R., 1988. Chumash Social Organization: An Ethnohistoric Perspective. University of California, Santa Barbara, Santa Barbara.

Johnson, J.R., 2004. Social responses to climatic change among the Chumash Indians of South-Central California. In: Jones, T.L., Raab, L.M. (Eds.), Prehistoric California: Archaeology and the Myth of Paradise. The University of Utah Press, Salt Lake City, Utah, pp. 149-159.

Johnson, J.R., 2007. Ethnohistoric descriptions of Chumash warfare. In: Chacon, R.J., Mendoza, R.G. (Eds.), North American Indigenous Warfare and Ritual Violence. University of Arizona Press, Tucson, pp. 74-113.

Johnson, J.R., 2010. Chumash islanders during the protohistoric and historic periods. In: Glassow, M.A. (Ed.), Channel Islands National Park Archaeological Overview and Assessment. Department of the Interior, National Park Service, Channe Islands National Park, Ventura, California, pp. 3-19.

Johnson, J.R., Monroe, C., Kemp, B.M., Lorenz, J.G., 2012. A land of diversity: genetic insights into ancestral origins. In: Jones, T.L., Perry, J.A. (Eds.), Contemporary Issues in California Archaeology. Walnut Creek, California, pp. 48-72.

Jones, T., Brown, G.M., Raab, L.M., McVickar, J.L., Spaulding, W.G., Kennett, D.J., York, A., Walker, P.L., 1999. Environmental imperatives reconsidered: demographic crises in western North America during the Medieval Climatic Anomaly. Curr Anthropol. 40, 137-210.

Jones, T.L., Ferneau, J., 2002. Deintensification along the central coast. In: Erlandson, J.M., Jones, T.L. (Eds.), Catalysts to Complexity: Late Holocene Societies of the California Coast. Cotsen Institute of Archaeology, University of California, Los Angeles, pp. 205-232.

Jones, T.L., Schwitalla, A., 2008. Archaeological perspectives on the effects of medieval drought in prehistoric California. Quatern. Int. 188, 41-58.

Jurmain, R., 2001. Paleoepidemiolgical patterns of trauma in a prehistoric population from central California. Am. J. Phys. Anthropol. 115, 13-23.

Jurmain, R., Bartelink, E.J., Leventhal, A., Bellifemine, V., Nechayev, I., Atwood, M. DiGiuseppe, D., 2009. Paleoepidemiological patterns of interpersonal aggression in a prehistoric central California population from CA-ALA-329. Am. J. Phys. Anthropol. 139, 462-473.

Jurmain, R., Bellifemine, V.I., 1997. Patterns of cranial trauma in a prehistoric population from central California. Int. J. Osteoarchaeol. 7, 43-50.

Keeley, L.H., 1996. War Before Civilization. Oxford University Press, New York.

Kelly, I., 1978. Coast Miwok. In: Heizer, R.F. (Ed.), California, Handbook of North American Indians, vol. 8. Smithosonian Institution Press, Washington D.C, pp. 414-425.

Kelly, R.C., 2000. Warless Societies and the Origins of War. University of Michigan Press, Ann Arbor.

Kennett, D.J., 2005. The Island Chumash: Behavioral Ecology of a Maritime Society. University of California Press, Berkeley, California.

Kennett, D.J., Kennett, J.P., 2000. Competitive and cooperative responses to climatic instability in coastal southern California. Am. Antiq. 65, 379-395 
Kennett, D.J., Lambert, P.M., Johnson, J.R., Culleton, B.J., 2013. Sociopolitical effects of bow and arrow technology in prehistoric Coastal California. Evol. Anthropol. 22, 124-132.

Kephart, H., 1917. The Gold Hunters: A First-Hand Picture of Life in California Mining Camps in the Early Fifties. MacMillan Company, New York.

Komar, D., Buikstra, J.E., 2008. Forensic Anthropology: Contemporary Theory and Practice. Oxford University Press, Oxford.

Kroeber, A.L., 1908. A Mission Record of the California Indians, from a manuscript in the Bancroft Library. The University Press, Berkeley, California.

Kroeber, A.L., 1925. Handbook of the Indians of California. Government Printing Office, Washington D.C..

Kroeber, A.L., 1932. The Patwin and their neighbors. Univ. Calif. Publ. Am. Archaeol. Ethnol. 29, 253-423.

Lambert, P., 2007a. The osteological evidence for indigenous warfare in North America. In: Chacon, R.J., Mendoza, R.G. (Eds.), North American Indigenous Warfare and Ritual Violence. The University of Arizona Press, Tucson, pp. $202-$ 221.

Lambert, P.M., 1994. War and Peace on the Western Front: A Study of Violent Conflict and Its Correlates in Prehistoric Hunter-Gatherer Societies of Coastal California, Anthropology. University of California, Santa Barbara, Santa Barbara.

Lambert, P.M., 1997. Patterns of violence in prehisotric hunter-gatherer societies of coastal southern California. In: Martin, D.L., Frayer, D.W. (Eds.), Troubled Times: Violence and Warfare in the Past. Routledge, New York, pp. 77-110.

Lambert, P.M., 2002. The archaeology of war: a North American perspective. J. Archaeol. Res. 10, 207-241.

Lambert, P.M., 2007b. Ethnographic and linguistic evidence for the origins of human-trophy taking in California. In: Chacon, R.J., Dye, D.H. (Eds.), The Taking and Displaying of Human Body Parts as Trophies by Amerindians. Spinger, New York, pp. 65-89.

Lambert, P.M., 2012. War histories in evolutionary perspective: insights from prehistoric North America. In: Shackelford, T.K., Weekes-Shackelford, V.A. (Eds.), The Oxford Handbook of Evolutionary Perspectives on Violence Homicide, and War. Oxford University, New York, pp. 324-338.

Latta, F.F., 1949. Handbok of the Yokuts Indians. Bear State Books, Santa Cruz, California.

LeBlanc, S.A., 1999. Prehistoric Warfare in the American Southwest. University of Utah Press, Salt Lake City, Utah.

Lightfoot, K.G., Parrish, O., 2009. California Indians and Their Environment. University of California Press, Berkeley, California.

Lovell, N.C., 1997. Trauma Analysis Paleopathology. Yearbook Phys. Anthropol. 40, 139-170.

Lowie, R.H., 1939. Ethnographic notes on the Washo. Univ. Calif. Publ. Am. Archaeol. Ethnol. 36, 301-352.

Margolin, M., 1978. The Ohlone Way. Heyday Books, Berkeley, California.

Margolin, M., 1989. The Journals of Jean Francois La Pérouse. Heyday Books, Berkeley, California.

Martin, D.L., Frayer, D.W., 1997. Troubled Times: Violence and Warfare in the Past. Routledge, New York

Maschner, H.D.G., 1997. The evolution of Northwest coast warfare. In: Martin, D.L., Frayer, D.W. (Eds.), Troubled Times: Violence and Warfare in the Past. Gordon and Breach, Amsterdam, pp. 267-302.

Maschner, H.D.G., Reedy-Maschner, K.L., 1998. Raid, retreat, defend (repeat): the archaeology and ethnohistory of warfare on the north pacific rim. J. Anthropol. Archaeol. 17, 19-51.

McCarthy, F.F., 1958. The History of Mission San Jose California 1797-1835: with an epilogue covering the period from 1835 to 1855 by Raymond F. Wood. Academy Library Guild, Fresno, California.

McCorkle, T., 1978. Intergroup conflict. In: Heizer, R.F. (Ed.), California, Handbook of North American Indians. Smithosonian Institution Press, Washington, D.C., pp. 694-700, Vol. 8.

Merbs, C.F., 1989. Trauma. In: Iscan, M.Y., Kennedy, K.A.R. (Eds.), Reconstruction of Life From the Skeleton. Alan R. Liss Inc, New York, pp. 161-190.

Merriam, C.H., 1955. Tribes of the Wintoon Stock. In: Bennyhoff, J.A., Gifford, E.W. Kroeber, A.L., McCown, T.D. (Eds.), Studies of the California Indians. University of California Press, Berkeley, California.

Milner, G.R., Anderson, E., Smith, V.G., 1991. Warfare in late prehistoric west-central Illinois. Am. Antiq. 56, 581-603.

Milner, G.R., Chaplin, G., Zavodny, E., 2013. Conflict and societal change in late prehistoric eastern North America. Evol. Anthropol. 22, 96-102.

Mooney, J., 1890. Notes on the Cosumnes tribes of California. Am. Anthropol. 3. 259-262.

Moratto, M.J., 1984. California Archaeology. Academic Press Inc, Orlando.

Morgan, D.L., Scobie, J.R., 1964. Three Years in California: William Perkin's Journal of Life at Sonora, 1849-1852. University of California Press, Berkeley, California.
Nelson, J.S., 1997. Interpersonal Violence in Prehistoric Northern California: A Bioarchaeological Approach. California State University, Chico Chico.

Otterbein, K.F., 1999. A history of research on warfare in anthropology. Am. Anthropol. 101, 794-805.

Palóu, F. 1774. The incident at the mission of San Antonio. In: Bolton, H.E. (Ed.) Historical Memoirs of New California, vol. IV. University of California Press, Berkeley, California, pp. 37-38.

Palóu, F., 1776. Occurence at this mission of our seraphic father San Francisco. In: Bolton, H.E. (Ed.), Historical Memoirs of New California, vol. IV. University of California Press, Berkeley, California, pp. 135-138.

Pastron, A.G., Clewlow, C.W.J., Atkinson, P.T., 1973. Aboriginal warfare in northern California: preliminary observations from skeletal material. The Masterkey 47, 136-142.

Peterson, D., Wrangham, R., 1996. Demonic Males: Apes and the Origins of Human Violence. Houghton Mifflin Company, New York.

Powers, S., 1877. Tribes of California. Contributions to North American Ethnology, vol. III. Washington, D.C.

Preston, W., 2004. Serpent in Eden: dispersal of foreign diseases into pre-mission California. In: Raab, L.M., Jones, T.L. (Eds.), Prehistoric California: Archaeology and the Myth of Paradise. University of Utah Press, Salt Lake City, Utah.

Priestly, H.I.T., 1937. A Historical, Political, and Natural Description of California By Pedro Fages: Written for the Viceroy in 1775. University of California Press, Berkeley, California.

Raab, L.M., Larson, D.O., 1997. Medieval Climatic Anomaly and punctuated cultural evolution in coastal southern California. Am. Antiq. 62, 319-336.

Schuster, I., 2006. Women's aggressions: an African case study. Aggres. Behav. 9, 319-331.

Schwitalla, A., 2010. The Medieval Climatic Anomaly in Central California: Environmental Imperatives Reconsidered from a Bioarchaeologial Perspective, Anthropology. California State University, Sacramento, Sacramento.

Schwitalla, A.W., 2013. Global Warming in California: A Lesson from the Medieval Climatic Anomaly (A.D. 800-1350). Center for Archaeological research at Davis No. 17. University of California Davis, Davis, California.

Schwitalla, A.W., Jones, T.L., 2012. A land of many seasons: bioarchaeology and the medieval climatic anomaly hypothesis in central California. In: Jones, T.L., Perry, J.A. (Eds.), Contemporary Issues in California Archaeology. Left Coast Press, Walnut Creek, California, pp. 93-114.

Shipley, W.F., 1978. Native Languages of California. In: Heizer, R.F. (Ed.), California, Handbook of North American Indians, vol. 8. Smithsonian Institution Press, Washington D.C., pp. 80-90.

Smith, M.O., 1997. Osteological indications of warfare in the Archaic period of the Western Tennessee valley. In: Frayer, D.W., Martin, D.L. (Eds.), Troubled Times: Violence and Warfare in the Past. Routledge, New York.

Stevens, N.E., Codding, B.F., 2009. Inferring the function of flaked stone projectile points from the central coast of Alta California. Calif. Archaeol. 1, 7-28.

Sutton, M.Q., 1986. Warfare and expansion: an ethnohistoric perspective on the Numic spread. J. Calif. Great Basin Anthropol. 8, 65-82.

Sutton, M.Q., Basgall, M.E., Gardner, J.K., Allen, M.W., 2007. Advances in understanding Mojave Desert prehistory. In: Jones, T.L., Klar, K.A. (Eds.), California Prehistory: Colonization, Culture, and Complexity. AltaMira Press, Lanham, California, pp. 229-246.

Taylor, A.S., 1856. Bibliografa Californica, 1510-1865. Sacramento Union, Sacramento, California.

Vayda, A., 1976. War in Ecological Perspective. Plenum, New York.

Voegelin, E.W., 1938. Tübatulabal Ethnography. Archaeological Records 2, 1-90. University of California Press, Berkeley, California.

Voegelin, E.W., 1942. Cultural Element Distribution: XX Northeastern California. University of California Anthropological Records 7, Berkeley, California.

Walker, P.L., 1989. Cranial injuries as evidence of violence in prehistoric southern California. Am. J. Phys. Anthropol. 80, 313-323.

Walker, P.L., Lambert, P.M., 1989. Skeletal evidence for stress during a period of cultural change in prehistoric California. In: Capasso, L. (Ed.), Advances in Paleopathology. Journal of Paleopathology: Monographic Publication No. 1, Chieti, Italy, pp. 207-212.

Wiberg, R.S., 2002. Archaeological Investigations: Skyport Plaza Phase I (CA-SCl478), San Jose, Santa Clara County, California. Submitted to Spieker Properties, San Jose, California. Holman and Associates Archaeological Consultants, San Francisco, California.

Wohlgemuth, E., 2004. The Course of Plant Food Intensification in Native Central California. University of California, Davis, Davis.

Worth, J.E., 1995. The struggle for the Georgia coast: an 18th-century Spanish retrospective on Guale and Mocama. Anthropological Papers of the American Museum of Natural History, No. 75. American Museum of Natural History, Athens, Georgia, New York. 